\title{
A CRITICAL ANALYSIS OF THE DEEP GEOLOGIC REPOSITORY SITING PROCESS IN ONTARIO
}

$$
\text { By }
$$

Anam Ahmad, Bachelor of Engineering (Mechanical Engineering), Ryerson University, 2014

\author{
A professional project paper \\ presented to Ryerson University \\ in partial fulfillment of the \\ requirements for the degree of \\ Master of Applied Science \\ in the Program of \\ Environmental Applied Science and Management
}

Toronto, Ontario, Canada, 2017

(C) Anam Ahmad 2017 


\section{AUTHOR'S DECLARATION}

I hereby declare that I am the sole author of this professional project paper. This is a true copy of the professional project paper including any required final revisions, as accepted by my examiners.

I authorize Ryerson University to lend this professional project paper to other institutions or individuals for the purpose of scholarly research.

I further authorize Ryerson University to reproduce this professional project paper by photocopying or by other means, in total or in part, at the request of other institutions or individuals for the purpose of scholarly research.

I understand that my professional project paper may be made electronically available to the public 
A Critical Analysis of the Deep Geologic Repository Siting Process in Ontario Master of Applied Science, 2017

\author{
Anam Ahmad \\ Environmental Applied Science and Management \\ Ryerson University
}

\begin{abstract}
This research paper is a case study of OPG's siting process for a low and intermediate level radioactive waste facility. The chosen site is in Kincardine, Ontario, where nuclear waste is currently stored above ground. The Town of Kincardine is in support of the project; however, several individuals and organizations are actively opposing the facility. The objective of this paper is to understand why the facility is facing so much opposition, what steps could have been taken to prevent it and how to proceed with the project plan. An inductive analysis of qualitative data was performed using explanation building and pattern matching. Lessons were drawn from cooperative siting guidelines specific to nuclear waste repositories in Ontario. The conclusion was drawn that omission of extensive public consultation in the siting process resulted in significant public opposition. Increasing community involvement when moving forward with the project may assist in reducing public opposition.
\end{abstract}




\section{ACKNOWLEDGMENTS}

I would like to thank Professor David Naylor for all his support and guidance as my project supervisor, Professor Cory Searcy and Professor Christopher Gore for being on my examining committee, the faculty and staff and Ryerson University that helped me along my

journey, my friends and family for their encouragement, support and patience and God for everything. 


\section{TABLE OF CONTENTS}

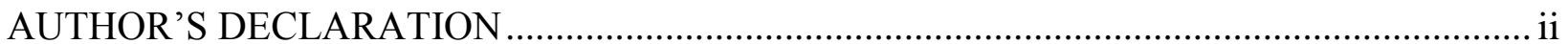

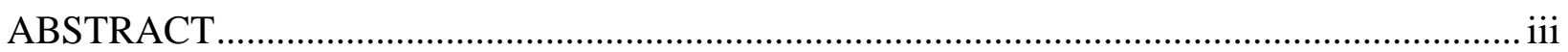

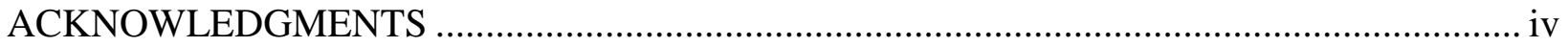

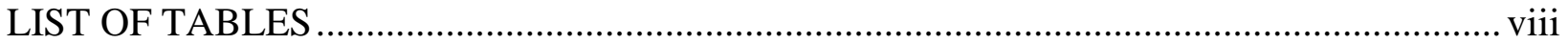

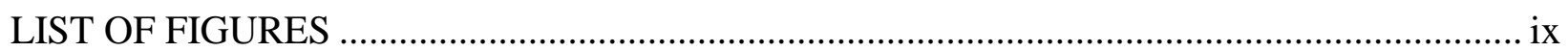

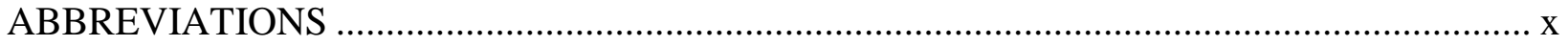

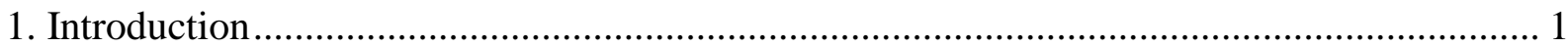

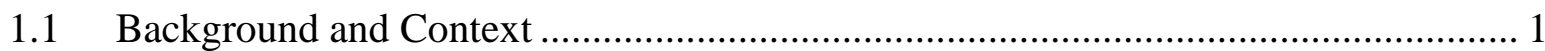

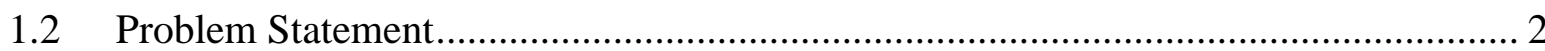

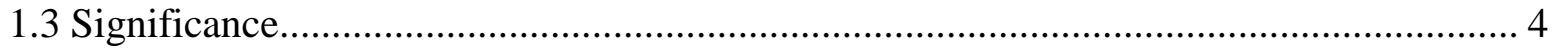

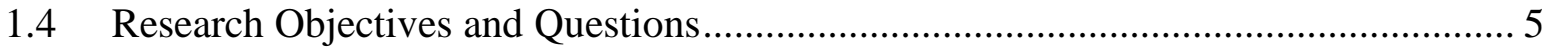

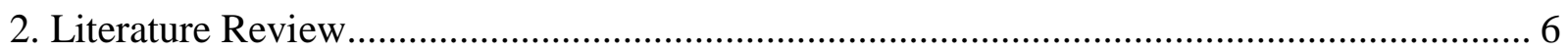

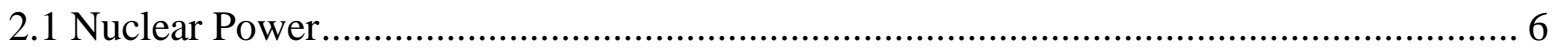

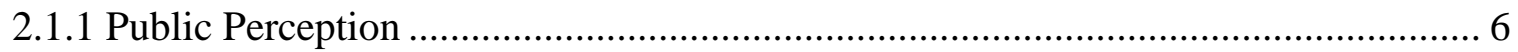

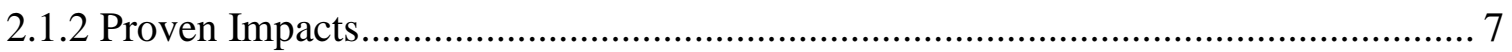

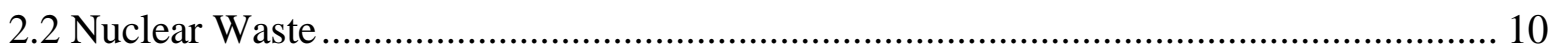

2.3 Nuclear Waste Management ............................................................................ 11

2.3.1 Nuclear Waste Management in Ontario.......................................................... 12

2.4 Traditional Hazardous Facility Siting ................................................................. 13

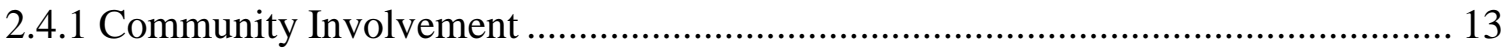

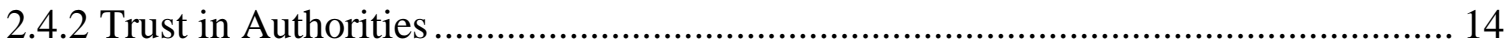

2.4.3 Perceived Risks and Benefits...................................................................... 15 


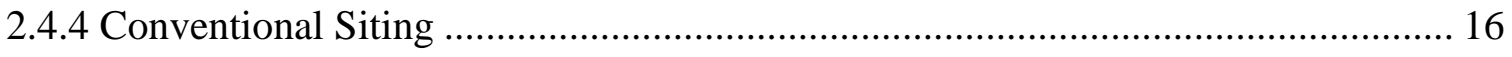

2.4.5 Cooperative Method............................................................................................. 17

2.5 Siting of Other Nuclear Facilities in Ontario ............................................................... 19

2.5.1 AECL Siting Recommendations ................................................................... 19

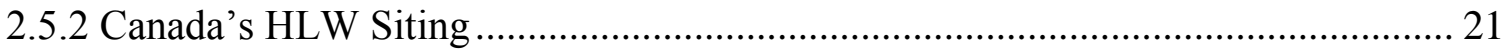

2.5.3 Low Level Radioactive Waste Siting Task Force...................................................... 21

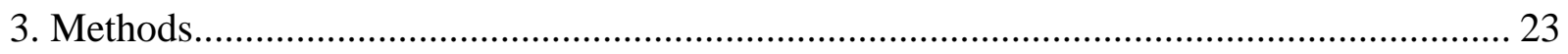

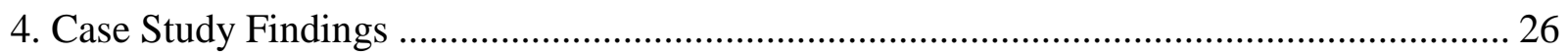

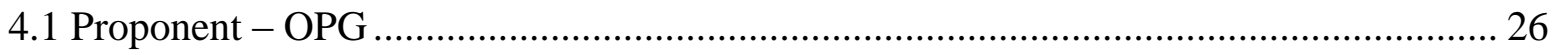

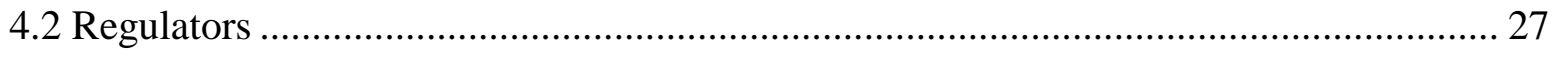

4.2.1 Canadian Environmental Assessment Agency (CEAA) ........................................ 27

4.2.2 Joint Review Panel................................................................................................ 27

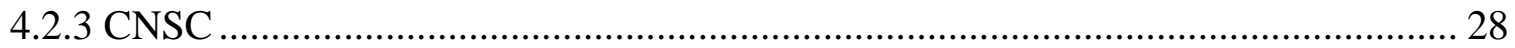

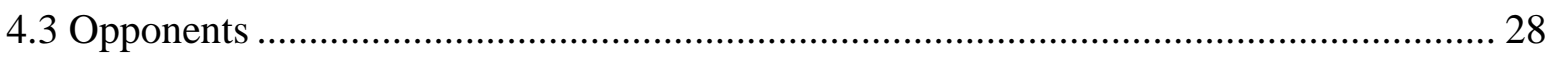

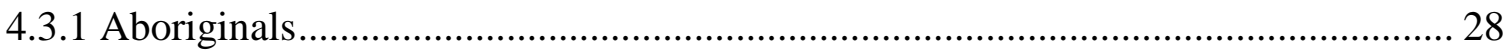

4.3.2 International Stakeholders ............................................................................ 29

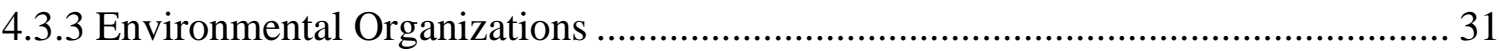

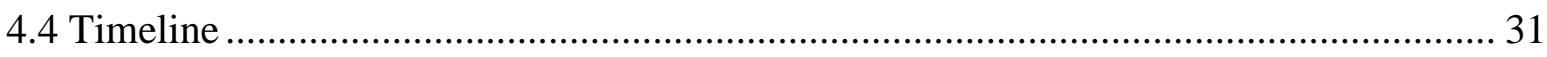

4.5 Environmental Assessment ................................................................................... 33

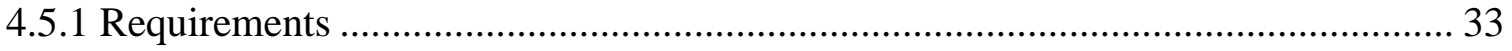

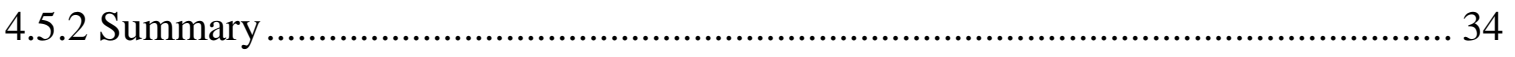

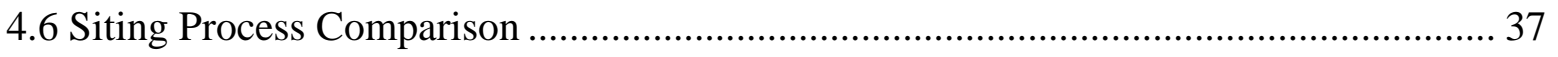

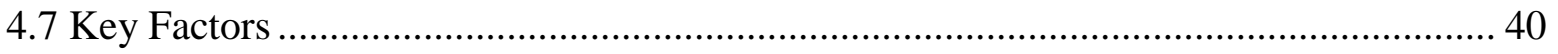

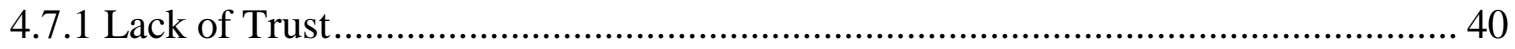




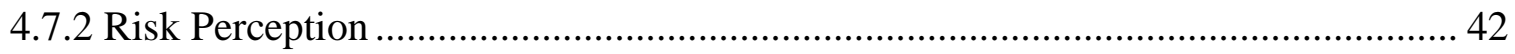

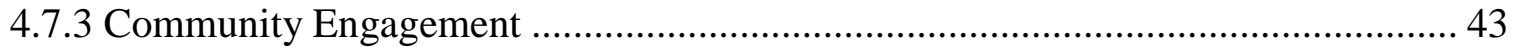

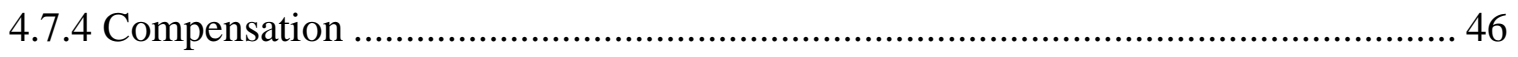

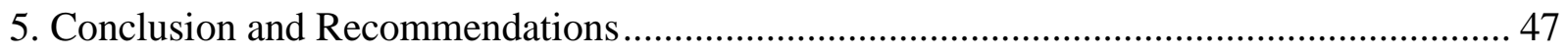

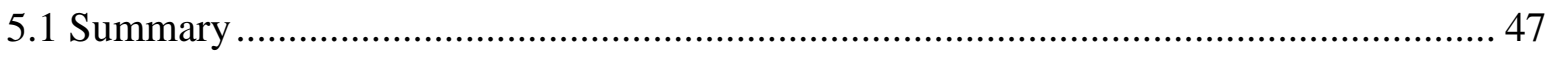

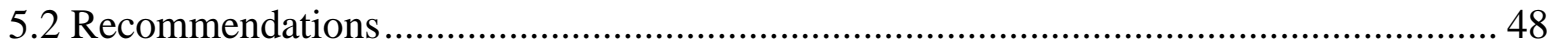

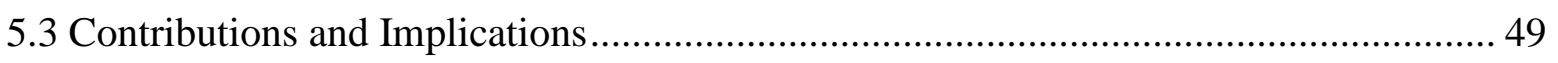

5.4 Limitations and Future Work............................................................................ 49

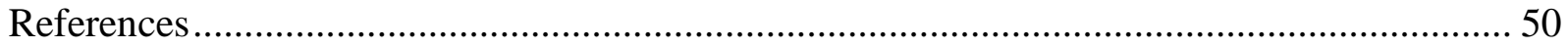




\section{LIST OF TABLES}

Table 1. Immediate fatalities by energy source …........................................................... 8

Table 2. Health Effects in Europe by Fuel Source............................................................... 9

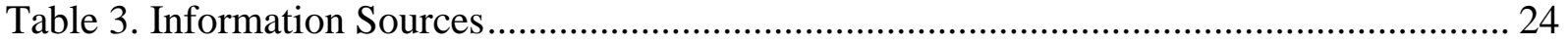




\section{LIST OF FIGURES}

Figure 1. DGR Opposition Communities ....................................................................... 3

Figure 2. Deaths and Illnesses by Fuel Source ........................................................ 9

Figure 3. Public Confidence in Canadian Institutions in 2013 .......................................... 15

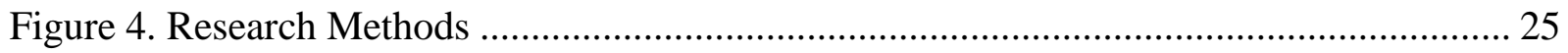

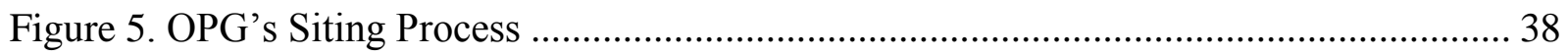

Figure 6. A Cooperative Siting Process Applied to OPG's DGR ........................................ 39

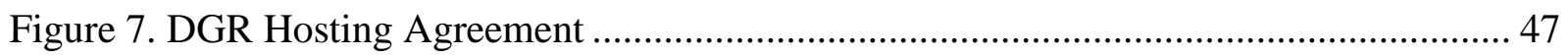




\section{ABBREVIATIONS}

AECB

AECL

CEAA

CELA

CNSC

DGR

EA

GIS

HLW

IJC

ILW

JRP

L\&ILW

LLW

NWMO

OPG

SON

USGS

WIPP

WWMF
Atomic Energy Control Board

Atomic Energy of Canada Limited

Canadian Environmental Assessment Agency

Canadian Environmental Law Association

Canadian Nuclear Safety Commission

Deep Geologic Repository

Environmental Assessment

Geographic Information System

High Level Waste

International Joint Commission

Intermediate Level Waste

Joint Review Panel

Low and Intermediate Level Waste

Low Level Waste

Nuclear Waste Management Organization

Ontario Power Generation

Saugeen Ojibway Nation

United States Geological Survey

Waste Isolation Pilot Plant

Western Waste Management Facility 


\section{Introduction}

\subsection{Background and Context}

Ontario Power Generation (OPG) has been safely storing radioactive waste at the Western Waste Management Facility (WWMF) in Kincardine, Ontario for the past 40 years (OPG 2016). In 2004, OPG decided that a deep geologic repository (DGR) is the superior option for storing radioactive waste (OPG 2004). A DGR is an underground storage facility that is constructed similar to a mine. The favourable characteristic of a DGR is that it safely isolates radioactive waste from the environment using an engineered and a geologic barrier. DGRs have been considered a viable method for storing nuclear waste worldwide for several decades. DGRs exist around the world in Germany, Sweden, Finland and the USA. Ten other countries, including Canada, are either proposing to construct or are siting a DGR (World Nuclear Association 2016).

This paper is a case study of a proposed DGR for low and intermediate level nuclear waste (L\&ILW) in Southern Ontario. In the proposed facility, two shafts connect the surface to a facility constructed deep in the ground made of tunnels, service areas and emplacement rooms where nuclear waste is stored in containers (OPG 2016). The L\&ILW DGR is proposed to be constructed $1.2 \mathrm{~km}$ inland from the shores of Lake Huron and $680 \mathrm{~m}$ deep. The precise location is within the exclusion zone of Bruce A and B Nuclear Generating Stations which is located in Kincardine (OPG 2014). The location is composed of sedimentary rock of high mechanical strength and low permeability that has been stable for hundreds of millions of years, even throughout mountain forming. The area is considered virtually dry as it contains traces of evaporated seawater. This means that this water has been isolated from the environment for millions of years (OPG 2016). Numerous external experts, speaking on behalf of OPG, state that the rock is predictable because it is made up of large, horizontally layered formations of sedimentary shale and limestone (OPG 2016).

The repository expects to accommodate $200,000 \mathrm{~m}^{3}$ of waste; about $90 \%$, of the waste stored in this facility would be low-level waste (LLW) with intermediate level waste (ILW) only accounting for $10 \%$ (OPG 2014). The facility would encompass an area of 40 hectares underground as well as 30 hectares above ground for related infrastructure such as a ventilation building and packaging facilities (Swanson et al. 2015). The lifespan of the project is projected to be 60 years which includes the construction, operation and decommissioning of the facility; 
after this time frame the repository will be full and the facility is then to be abandoned forever (Swanson et al. 2015). Government agencies, including the Canadian Nuclear Safety Commission (CNSC), are to oversee all project activities. The construction phase will follow standard mine construction methods, the operation phase will use wisdom from conventional radioactive waste disposal practices and the decommissioning phase would include mitigation and follow-up where necessary (Swanson et al. 2015).

OPG expected to receive the license to prepare the site and construct the facility in 2014 and the license to operate after a five to seven year long construction phase (OPG 2013). The final step before receiving the license to prepare the site and construct the facility is for the Minister of Environment to approve the project's environmental assessment (EA) report. The project was delayed when the Minister of Environment and Climate Change, Catherine McKenna, requested additional information on the EA on February 18, 2016. OPG committed to providing that information by December 31, 2016. The project cannot expect to be approved until the year 2017.

The focus of this research project is the siting process for the L\&ILW DGR proposed by OPG in the Town of Kincardine, Ontario. OPG has chosen Kincardine as a suitable site for a DGR for the long-term storage of L\&ILW. This decision was made without following any structured siting process because the Town of Kincardine approached OPG with a request to construct a DGR. Nuclear waste is currently stored above ground at the same site. This request is supported by the two characteristics that OPG cites as the most important for a DGR location: community support and geologic stability.

\subsection{Problem Statement}

In Ontario, baseload electrical energy demand is being met by nuclear energy. This reduces concerns regarding air quality and $\mathrm{CO}_{2}$ emissions, which are the most significant human and environmental health issues that arise from fossil fuel combustion. However, nuclear energy brings with it a completely new set of challenges. The inability to effectively manage nuclear waste is one of the greatest technical challenges that the nuclear industry faces. Until there is an acceptable, long-term waste storage plan, nuclear waste will remain a point of contention for the anti-nuclear community. The residents of Southern Ontario have accepted the construction and operation of nuclear energy production facilities near their homes because it is understood to be 
the best alternative to fossil fuel power plants. That same community is now voicing concerns over the challenge of managing the great volume of nuclear waste generated in the process. A DGR is a novel facility that is surrounded by a great amount of perceived risk. Figure 1 is a map created by an anti-DGR group called Stop the Great Lakes Nuclear Dump, which outlines all the communities that oppose the project.

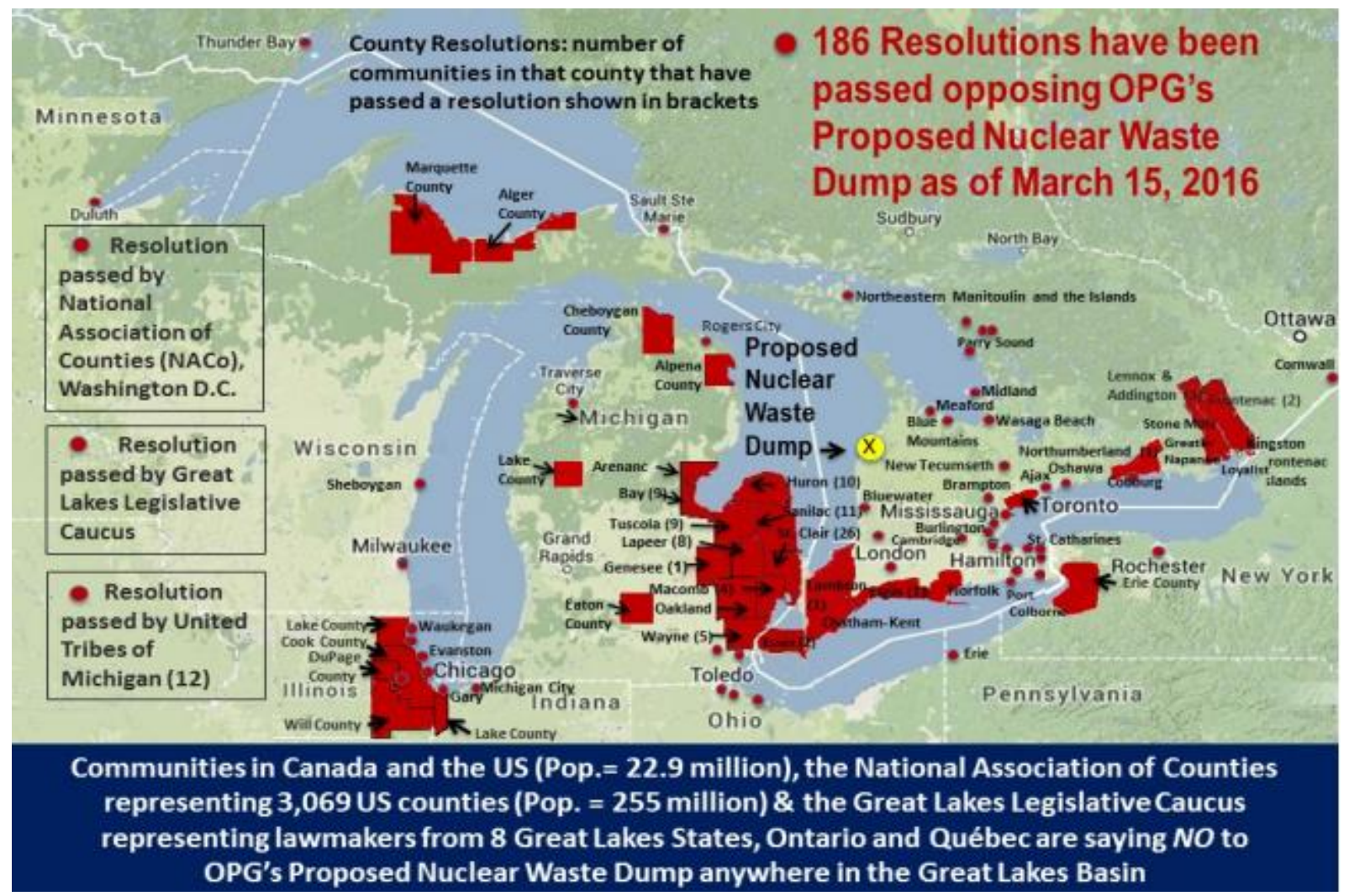

Figure 1. DGR Opposition Communities (Stop the Great Lakes Nuclear Dump 2016)

The Town of Kincardine, Ontario has been chosen as the suitable site for a DGR by OPG for the long-term storage of L\&ILW. While the Town of Kincardine is in support of the proposed DGR, surrounding communities are not as comfortable with the existence of such a site so close to their homes. The resistance consists of members of surrounding towns, Aboriginal groups in the area and international communities as well, all of which can be considered stakeholders in the proposed DGR project.

The purpose of this study is to analyze the siting process of the proposed DGR for Ontario's L\&ILW. This study will include a comparison to the siting process for a high-level nuclear waste (HLW) DGR. The siting process for nuclear fuel waste (HLW) disposal follows guidelines 
suggested by Atomic Energy of Canada Limited (1994). A similar set of guidelines exists for LLW; a siting taskforce was created in the 1980s to determine the ideal siting process for a LLW storage in Ontario, not specific to a geologic repository facility. One objective of the current study is to determine if, and how much, OPG could have benefited by applying these previously composed guidelines to site the L\&ILW DGR.

Understanding what was lacking in the siting process that fueled a great deal of opposition may also aid OPG in resolving conflicts with the various communities that have voiced their opinions against the proposed site. This study will also stress the importance of inclusion in the siting process, inclusion of anyone who reasonably identifies himself or herself as a stakeholder.

\subsection{Significance}

The proposed DGR in Kincardine holds a great amount of significance for OPG and the residents of Ontario. Identifying opportunities for improvement in the siting process of a L\&ILW DGR could prove to be beneficial for any related projects in the near future.

An inventory completed by the Low-Level Radioactive Waste Management Office shows that by the end of 2010 Canada generated 2.38 million cubic meters of high, intermediate and low-level radioactive waste from the nuclear energy industry (2013). The majority of this waste is generated in Ontario, which houses sixteen of Canada's eighteen nuclear reactors (World Nuclear Association 2015). The Kincardine DGR is designed to house just 200,000 cubic meters of nuclear waste, $90 \%$ of which will be LLW (OPG 2014). These numbers imply that there may be a need for more than one LLW DGR in Ontario in the near future. Understanding where problems arose may also aid OPG in resolving conflicts with the various communities that have voiced their opinions against the proposed site. This study will also stress the importance of inclusion in the siting process-- inclusion of anyone who reasonably identifies himself or herself as a stakeholder. A stakeholder is defined as a person or group of people who can be or think they can be affected by the outcome of a decision or project (Stakeholder Map 2015). Storage of nuclear waste is not only an issue for OPG; it is a shared challenge by the citizens that rely on the power generated by OPG. Therefore, all residents of Southern Ontario should desire safe solutions. A survey performed by the NWMO shows that $87 \%$ of Canadians prefer that nuclear waste be stored in remote areas, this survey alone shows that the majority of Canadians would be opposed to a DGR located in an area as populated as the Great Lakes Basin (2008). 
On a larger scale, this research is important because there is a lack of information on the siting of a L\&ILW repository. Through the literature review, ample sources on the siting of a HLW DGR were found while only one source for LLW was found, and none for ILW. The lack of information on LLW and ILW DGRs indicates how important it is to study this aspect of facility siting. The siting of a LLW \& ILW repository is just as important as a HLW repository because the general public cannot distinguish between the three levels of nuclear waste. Additionally, L\&ILW contamination does pose some threat to the environment. This threat is not as serious as it is for HLW but still cannot be ignored.

HLW is significantly more radioactive than L\&ILW; however, LLW is the main contributor to nuclear waste in terms of volume (World Nuclear Association, 2015). From any one reactor, LLW accounts for $90 \%$ of nuclear waste by volume and yet HLW contains over $90 \%$ of the total radioactivity (World Nuclear Association, 2015). These numbers demonstrate two important realities of nuclear waste management: one is that a DGR for HLW should have much more stringent design requirements than a DGR for L\&ILW due to increased radioactivity, and the other is that a long-term waste management plan is crucial for low-level waste because it is generated in high volumes. The logical decision to be made from these two facts is that there is an urgent need for a LLW DGR, especially for a province that is as heavily dependent on nuclear energy as Ontario is. While it is clear that OPG has invested a great amount of resources into the design of the DGR, that places safety above all other design criteria, it is also clear that an inadequate amount of resources was used in the siting process of the Kincardine DGR.

\subsection{Research Objectives and Questions}

The objective of this research is to highlight the importance of a structured siting process for the Kincardine DGR. Instead of brushing off community concerns as NIMBYism, this report provides an overview of the rationale for public opposition to this facility. NIMBYism implies that the public is selfish and irrational which tends to further fuel opposition (Wolsink 1992). In addition, this research will serve as a best practice guideline for siting a DGR. The research questions that will be answered are: "Why is there so much opposition to the proposed L\&ILW DGR? How could that opposition have been minimized?" and "What steps can be taken moving forward to gain community support?" 


\section{Literature Review}

\subsection{Nuclear Power}

Nuclear power plants generate power the same way as conventional natural gas plants, the only difference is that the heat source is obtained from the controlled splitting of uranium nuclei, also known as nuclear fission, a process that releases a high amount of heat energy.

Traditional energy production is one of the most polluting activities that humans carry out. Along with energy, fossil fuel plants produce various by-products that pollute the atmosphere such as carbon monoxide, carbon dioxide, sulfur dioxide, nitrogen oxides, particulate matter and volatile organic compounds. The large scale presence of these compounds in the environment is a contributor to global warming, acid rain deposition, smog and other detrimental environmental phenomenon that ultimately result in ecosystem and human health degradation. In order to minimize this impact various alternative fuel sources have emerged to replace coal, oil and natural gas energy production. One alternate fuel source is uranium.

Uranium is a non-renewable resource although small amounts of it can produce a significant amount of energy. The nucleus of a uranium atom contains a high amount of energy, which is released when the nucleus is split by nuclear fission. That energy can be used to turn a turbine for generating electricity (National Geographic Education 2016). In a nuclear energy plant, a controlled fission reaction occurs in a reactor, which serves as the heat source for a power generation station. Aside from uranium mining and other secondary activities, nuclear power production emits no greenhouse gasses into the environment. This factor makes nuclear energy appear to be a promising solution to traditional polluting energy fuel sources. Unfortunately, nuclear energy brings with it new environmental concerns, such as the effects of radiation and the management of nuclear waste.

\subsubsection{Public Perception}

Public perceptions surrounding nuclear power are often overshadowed by the memory of various nuclear power plant accidents. Perrow describes an accident as an event that causes damage to people or objects to the extent where they can no longer carryout their designed function (1999). In 1986, a reactor at the Chernobyl Nuclear Power Plant ruptured and caused 31 immediate deaths and 145 latent deaths (Rashad and Hammad 2000). A $30 \mathrm{~km}$ exclusion zone 
was created around the facility and about 200, 000 residents had to relocate. This accident left people and entire towns incapable of fulfilling their purpose (Rashad and Hammad 2000). Chernobyl and other less catastrophic accidents, such as Three Mile Island in 1979 and Fukushima Daiichi in 2011, tend to resonate with the public and create the base for skeptical perceptions surrounding nuclear power plants. The public's concern does not stem solely from accidents but also from concern for the environment and lack of faith in the government (Stoutenborough, Sturgess and Vedlitz 2013).

Risk is perceived and handled in three ways: emotionally, technically or politically. When someone has an emotional approach to risk, they use their values, worldviews and feelings to define the magnitude and probability of the risk. A technical approach to risk perception uses science, logic and reason to define a risk. When the emotional and technical approach to risk are in conflict with one another, risk is defined in a political manner (Slovic 1999). The solution to a perceived risk depends on the definition of that risk and a risk can be defined in many ways. Therefore, the one who has the power to define the risk also has the power to define the solution. Risk perception becomes political when deciding who should define the risk and how.

The general public tends to perceive risks emotionally more often than technically. This is because they are not provided with the information or the methods needed to derive a technical approach to risk. Scientists depend on technical risk definitions and solutions and only provide the public with the result of that solution. Naturally, the public is critical of the result since they cannot derive that result for themselves. This is why it is important to educate the public on the scientific methods and the details of a risk scenario. This would help increase familiarity with the risk, which would decrease the perceived threat of that risk.

\subsubsection{Proven Impacts}

Proven impact studies for nuclear reactors often include normal operations as well as effects of potential accidents. One such study was performed for a proposed nuclear facility in Nigeria. This study focussed on radioactive air emissions by modeling the radioactive plume in the proposed location using the software AERMOD (Aliyu, Ramli and Saleh 2015).

Conservative estimates were used to model air concentration and deposition of radionuclides and it was found that they are not present in concentrations that can cause significant adverse health effects; the likelihood of exceeding the standard screening dose limit of a $10 \mu \mathrm{G} / \mathrm{h}$ was less than 
5\%. Radionuclides are thought to be no-threshold linear contaminants; therefore, they will not have a toxic effect on humans as long as the total exposure remains below the experimentally derived threshold concentration. Beyond that threshold, an increase in exposure results linearly in an increase of disease incidence (Canadian Nuclear Safety Commission 2015). Alternatively, it was also mentioned that in the case of routine discharges and possible accidents, the effects are indiscernible, despite that, radionuclide concentration can significantly surpass thresholds (Aliyu et al. 2015).

Many studies on the health effects of nuclear plants tend to compare the effects on human health caused by the nuclear industry with other energy sources. The findings of one study conducted in China show that the radiation risk to the public from the nuclear industry is two orders of magnitude lower than the risk from coal plants. The radiation risk to mining workers is three times higher in the coal industry compared to nuclear. The risk of accidents faced by coal miners is about 6 times greater than that faced by uranium miners (Ziqiang et al. 1999). Table 1 summarizes findings from another study, which shows the total fatalities from various energy sources during 1970-1992. The results show that if fatalities of fewer than five people are included, coal energy production takes 3.2 lives per GW of electrical power produced annually; comparatively nuclear power production has taken 0.01 lives per $\mathrm{GW}$ of energy produced annually. For nuclear power production, this study only takes into account the lives lost during the Chernobyl accident, latent fatalities were not included (Rashad and Hammad 2000).

Table 1. Immediate fatalities by energy source (Rashad and Hammad 2000)

\begin{tabular}{|c|c|c|c|c|}
\hline & \multirow[t]{2}{*}{ Events } & \multicolumn{2}{|l|}{ Fatalities } & \multirow{2}{*}{$\begin{array}{l}\text { Average fatalities per GW(e) } \\
\text { per annum }\end{array}$} \\
\hline & & Range & Total & \\
\hline Coala & 133 & $5-434$ & 6418 & 0.32 \\
\hline Oil & 295 & $5-500$ & 10273 & 0.36 \\
\hline Natural gas & 88 & $5-425$ & 1200 & 0.09 \\
\hline Liquid propane gas & 77 & $5-100$ & 2292 & 3.1 \\
\hline Hydro & 13 & $10-2500$ & 4015 & 0.8 \\
\hline Nuclear & 1 & 31 & 31 & 0.01 \\
\hline
\end{tabular}

a The total is some 10 times higher if accidents with less than five fatalities are included.

A study conducted in the United Kingdom yielded similar results. This study includes major and minor illnesses as well as deaths caused by air pollution from various fuel sources. It also categorizes deaths caused by accidents into two groups: occupational deaths and deaths among the public. The results are expressed as deaths/cases per TWh in Table 2. Just as in the 
above study, the impacts of air pollution effects from nuclear power production are several orders of magnitude lower than the other fuel sources; the only exceptions are accidental public deaths by biomass and accidental occupational deaths by gas, oil and biomass. Deaths and illnesses by air pollution are 2-3 times higher for all other fuel sources in comparison to nuclear power; this is clearly illustrated in Figure 2 below.

Table 2. Health Effects in Europe by Fuel Source (Markandya and Wilkinson 2007)

\begin{tabular}{|c|c|c|c|c|c|}
\hline & \multicolumn{2}{|c|}{ Deaths from accidents } & \multicolumn{3}{|c|}{ Air pollution-related effects } \\
\hline & Among the public & Occupational & Deaths* & Serious illness $\dagger$ & Minor illnessł \\
\hline Lignite $^{30}$ & $0.02(0.005-0.08)$ & $0.10(0.025-0.4)$ & $32 \cdot 6(8 \cdot 2-130)$ & $298(74 \cdot 6-1193)$ & $17676(4419-70704)$ \\
\hline Coal $^{p}$ & $0.02(0.005-0.08)$ & $0.10(0.025-0.4)$ & $24 \cdot 5(6 \cdot 1-98 \cdot 0)$ & $225(56 \cdot 2-899)$ & $13288(3322-53150)$ \\
\hline $\mathrm{Gas}^{31}$ & $0.02(0.005-0.08)$ & $0.001(0.0003-0.004)$ & $2 \cdot 8(0 \cdot 70-11 \cdot 2)$ & $30(7 \cdot 48-120)$ & $703(176-2813)$ \\
\hline Oil $\beta^{31}$ & $0.03(0.008-0.12)$ & $*$ & $18 \cdot 4(4 \cdot 6-73 \cdot 6)$ & $161(40 \cdot 4-645 \cdot 6)$ & $9551(2388-38204)$ \\
\hline Biomass $^{31}$ & .. & . & $4 \cdot 63(1 \cdot 16-18 \cdot 5)$ & $43(10 \cdot 8-172 \cdot 6)$ & $2276(569-9104)$ \\
\hline Nuclear $r^{31,32}$ & 0.003 & 0.019 & 0.052 & 0.22 & .. \\
\hline
\end{tabular}

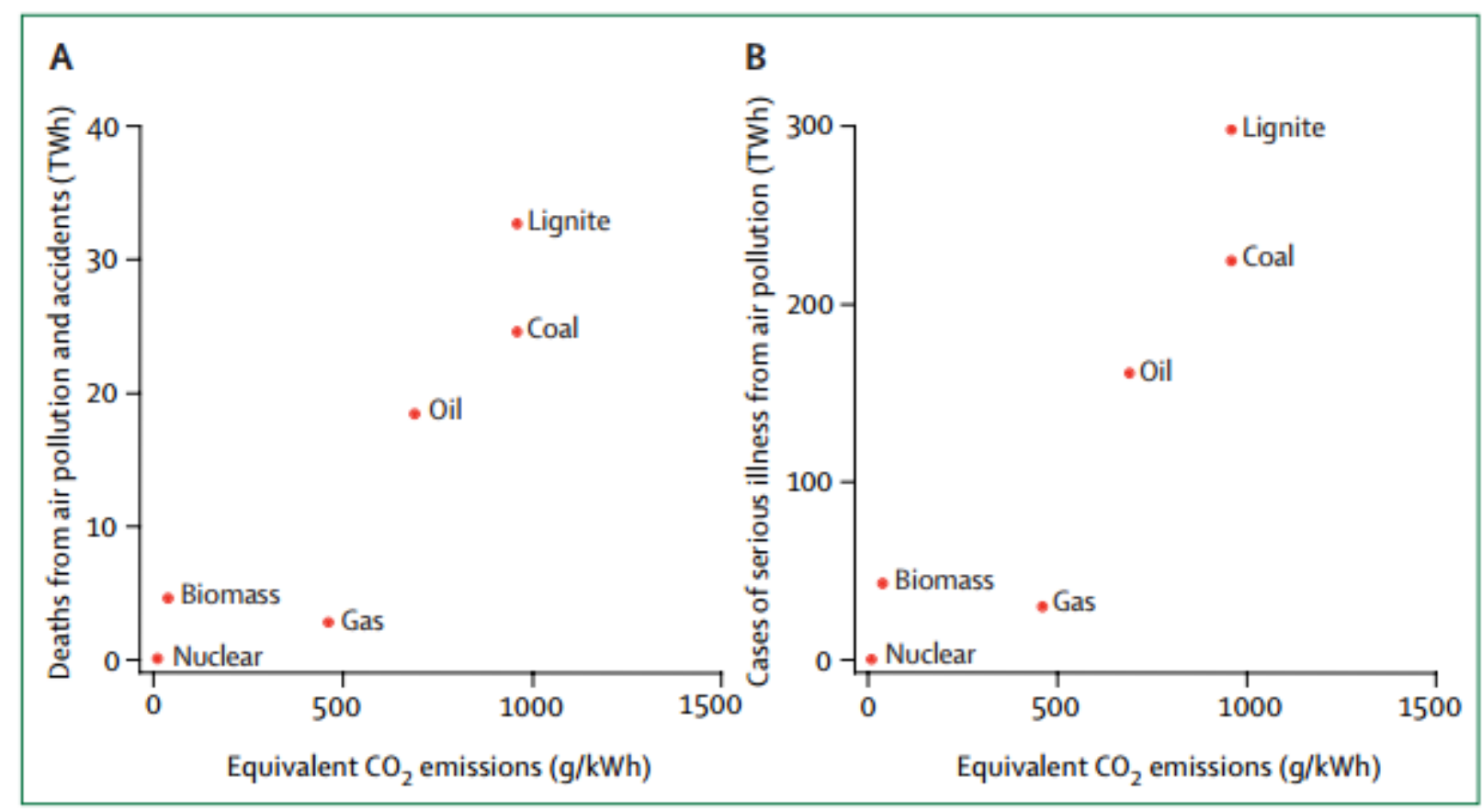

Figure 2. Deaths and Illnesses by Fuel Source (Markandya and Wilkinson 2007)

Nuclear energy is considered to have minimal adverse effects on human health during safe operation; however, catastrophic events can lead to immediate and latent fatalities and leave areas incapable of supporting life for a long period. Safe operation of these facilities is a top priority. 


\subsection{Nuclear Waste}

Nuclear waste is categorized as high, intermediate and low level waste and is classified according to activity concentration and contact dose rates. Activity concentration can be expressed in terms of $\mathrm{Bq} / \mathrm{m}^{3}$. A Bq, Becquerel, is the rate at which a radioactive material decays per second (U.S. Nuclear Regulatory Commission 2016). Contact dose rates provide information on human exposure to radioactivity over a certain time. Dose rates are measured in $\mathrm{mSv} / \mathrm{hr}$. A milliSievert, (mSv), is equivalent to 1 Joule/kg or energy per kilogram (U.S. Nuclear Regulatory Commission 2016). LLW is distinguished by contact dose rate and shielding requirements. LLW does not require shielding while handling and has a contact dose rate of less than $2 \mathrm{mSv} / \mathrm{hr}$. LLW can have an activity concentration up to $10^{10} \mathrm{~Bq} / \mathrm{kg}$. The absence of shielding requirements simplifies the storage of LLW. LLW has even been stored in shallow trenches in four U.S. states: Nevada, South Carolina, Utah and Washington (Hinrich and Kleinbach 2012).

Unlike LLW and HLW, there is no defined standard activity concentration level for ILW. ILW is defined at the discretion of individual waste management facilities. Generally, ILW consists of reactor components that contain long-lived radioactive nuclides that may emit alpha particles. For this reason, ILW requires shielding and is not considered suitable for near surface disposal. ILW is recommended to be stored several hundred meters underground (International Atomic Energy Agency 2009).

HLW requires more than just shielding, storage techniques must also accommodate heat dissipation. The activity concentration for HLW is in the range of $10^{4}-10^{6} \mathrm{TBq} / \mathrm{m}^{3}$ (International Atomic Energy Agency 2009). HLW is unlike L\&ILW because it contains actinides. Actinides is the term used to define the following 15 heavy radioactive metals on the periodic table: Actinium (Ac), Thorium (Th), Protactinium (Pa), Uranium (U), Neptunium (Np), Plutonium (Pu), Americium (Am), Curium (Cm), Berkelium (Bk), Californium (Cf), Einsteinium (Es), Fermium (Fm), Mendelevium (Md), Nobelium (No), Lawrencium (Lr). Only four actinides are naturally occurring, Ac, Th, Pa, and U (Murugen 2004). Pu, an actinide commonly found in HLW, has a half-life of 24000 years. Due to the presence of long-lived radioactive material, HLW must be isolated until it decays into harmless material (U.S. Nuclear Regulatory Commission 2015). 


\subsection{Nuclear Waste Management}

LLW is incinerated to reduce the volume of waste placed in long-term storage (OPG 2016). Incineration is a major emitter of Polychlorinated dibenzo-p-dioxins (PCDDs) and polychlorinated dibenzofurans (PCDFs). These toxins are known to be persistent and bioaccumulative. Incineration accounts for $22.5 \%$ of these toxic emissions nationwide (Environment and Climate Change Canada 2015). Mitigation measures to control the release of these substances include stringent new requirements that must be met by new incineration facilities and improved control technologies for existing facilities. Ultimately, the most efficient method of reducing PCDD and PCDF releases to the atmosphere is to incinerate less waste (Environment and Climate Change Canada 2015).

Safe operation of a nuclear power plant manages to contain high levels of radiation although the operation and decommissioning of a nuclear power plant generates a large amount of waste, at varying degrees of radioactivity. The safest way to manage this waste is to isolate it from the environment while radioactivity levels are dangerously high. Aboveground storage is considered inferior to geologic storage from a safety perspective.

The concept of deep geologic disposal first arose in the 1960s with various publications from the 1970s. Lawrence Livermore Laboratory in Arizona began their study of a potential DGR for HLW by modeling the societal risk evaluations (Heckman et al. 1978). Bredehoeft and Maini outlined in a Science article the important characteristics of a DGR site, the most important of which is to understand the movement of ground water (Bredehoeft and Maini 1978). The article proposes siting a DGR in crystalline rock underneath sedimentary rock. The article highlights the importance of having a strong understanding of the groundwater flow characteristics at the site. An ideal site should not be located near potable water and should act as an added barrier. This means that the flow characteristics of the groundwater aid in isolating the radioactive waste from the biosphere through slow movement and long movement passages. The US Geologic Survey (USGS) also released a report in 1978 detailing five important factors when siting a DGR. The first area requiring further research was the ability to identify sites with minimal drilling required. Second, the impact of waste and site construction on the rock. Third, the chemistry of salt-brine mixtures, present at some sites. Fourth, the chemistry and mechanics of mixtures other than salt. Fifth, groundwater movement and sorption properties (USGS, 1978). 
In this report, potential repository sites were also discussed. This included a site in Nevada. More recently, in the 1990s, Yucca Mountain in Nevada was rejected as a possible HLW DGR location. Much of the reasoning behind this rejection was due to public opposition.

However, this does not mean that other DGR sites did not have more success. At the time this report was published, research had already been conducted on a site called the Waste Isolation Pilot Plant (WIPP) in New Mexico, the site where the only HLW DGR in the world is located. The WIPP came into operation 20 years later in 1999 and in February 2014 a fire in the facility raised new concerns surrounding geologic disposal (Adams 2014). The fire not only highlighted the importance of stringent safe operation and evacuation procedures but also served as a reminder of the catastrophic result of the smallest mismanagement. Days after the fire, an unrelated event caused the release of contamination in insignificant doses to the surface (Adams 2014). The WIPP faces greater challenges than other DGRs in the world because it stores HLW. This means that risk perception is higher for the WIPP than for L\&ILW DGRs. Five L\&ILW DGRs exist in the world. One is in Sweden which has been in operation since 1988, two are in Finland that have been in operation since 1992 and 1998 and there are two more in Germany that have been closed since 1995 and 1998 (World Nuclear Association 2015). Many other DGRs around the world are either under construction, siting or awaiting approval (World Nuclear Association 2015). Such is the case for two possible DGRs in Ontario. One is for HLW, which is currently being sited by a lengthy process carried out by the Nuclear Waste Management Organization (NWMO), and the other is for L\&ILW for which the proponent, OPG, is awaiting approval.

\subsubsection{Nuclear Waste Management in Ontario}

In Ontario, there is a different method for handling each type of waste. HLW is spent nuclear fuel and continues to generate heat after being removed from the reactor (CNSC 2016). HLW is stored underwater for seven to ten years to cool the fuel bundles, which are heated by radioactive decay. Once thoroughly cooled they are transported to above ground facilities for long-term storage (CNSC 2016). ILW consists of reactor components, such as resins and filters, and can remain radioactive enough to require isolation for several thousands of years (CNSC 2016). In Ontario ILW is placed in steel lined concrete containers and set into the ground (CNSC 2016). LLW consists of rags, mops, shoe covers and other items that become radioactive through 
the daily operation of a nuclear facility; this waste must be isolated for at least 300 years (CNSC 2016). LLW is incinerated or tightly packaged, the ashes and bundles are then stored above ground at the WWMF (OPG 2016). Concerns are greatest for the storage of HLW and minimal

for LLW. The general public is not aware of this waste classification system, this means that nuclear waste is perceived as dangerous regardless of the classification level. The exception to this are citizens of municipalities that already host a nuclear facility, they may be more knowledgeable about nuclear waste classification.

\subsection{Traditional Hazardous Facility Siting}

Various studies have been performed on the siting of undesirable facilities and local acceptance. One such study was performed for a radioactive waste facility in Korea. Four important factors were identified in siting such a facility: risk perception, perceived economic benefit, trust and perceived competition. Other factors that impact the acceptance of a locally unacceptable land use are scientific knowledge, participation and political attitudes (Chung and Kim, 2009).

\subsubsection{Community Involvement}

Decades ago, the general public was ignorant of the hazards associated with various facilities; the lack of this important information made a population less likely to oppose a hazardous facility and left them incapable of making important decisions related to living a healthier, more comfortable lifestyle. Today, the public has access to a vast collection of information regarding those very hazards. In an ideal world, this information would serve the public by informing them of the potential risks they face if they live close to a hazardous facility. In reality, the public does not always refer to trusted sources for their information. The glorious information age has brought along with it the side effect that gives any member of society the power to have their unvetted opinion heard through various outlets, regardless of credentials. These voices may speak in exaggerated tones resulting in sensationalized information and inaccurate perceptions of hazardous facilities. Influencing a solidified perception is a significant challenge that must be overcome when siting a hazardous facility.

While it may seem that the increased access to information has increased the difficulties for a proponent of a hazardous facility, accurate information can serve as an aid for siting a hazardous facility. The community can use studies on the potential human and environmental 
health impacts of a facility to decide if the risk posed by the facility is acceptable. Community in this context is any local citizen or group of citizens who reasonably identify as stakeholders. Studies on existing facilities can be considered accurate and can show the potential benefits and drawbacks of a proposed similar facility. The proponent can then present this information in a transparent manner to ease concerns of nearby residents or alter the facility's design and location until it meets an acceptable health standard. Residents that already live near a hazardous facility usually have accurate information about the potential health and environmental effects. This may be due to information provided by the facility operator, research fueled by personal interest, or simply from personal experience.

\subsubsection{Trust in Authorities}

There are tools and techniques available to help members of the public navigate the ocean of information available to them. For example, a journal that is peer reviewed is more reliable than an unregulated website or a journal that publishes articles for a fee. Credible journal articles are often only referenced for academic purposes; very few people study journal articles for general knowledge. Another important aspect of information credibility is the source. For example, one would expect that information from the government or an academic institution is more reliable than information retrieved from a personal blog. This is not necessarily the case due to the lack of public trust for authority and science. Statistics Canada carried out a survey on public confidence in Canadian institutions in 2013. The results showed that $38 \%$ of respondents had some confidence in federal parliament; an even lower $10 \%$ expressed having a great deal of confidence. Only $30 \%$ of respondents had some confidence in major corporations; only $6 \%$ expressed high confidence (Cotter 2015). Figure 3 below illustrates what a small percentage of Canadians have great confidence in government authorities and corporations. The survey also found that aboriginals were more likely to express less confidence in federal parliament and the justice system than non-aboriginals. Low levels of confidence were also reported for Canadian media (Cotter 2015). This implies that the public prefers to get their information from nontraditional media sources, possibly giving greater preference to social media. 


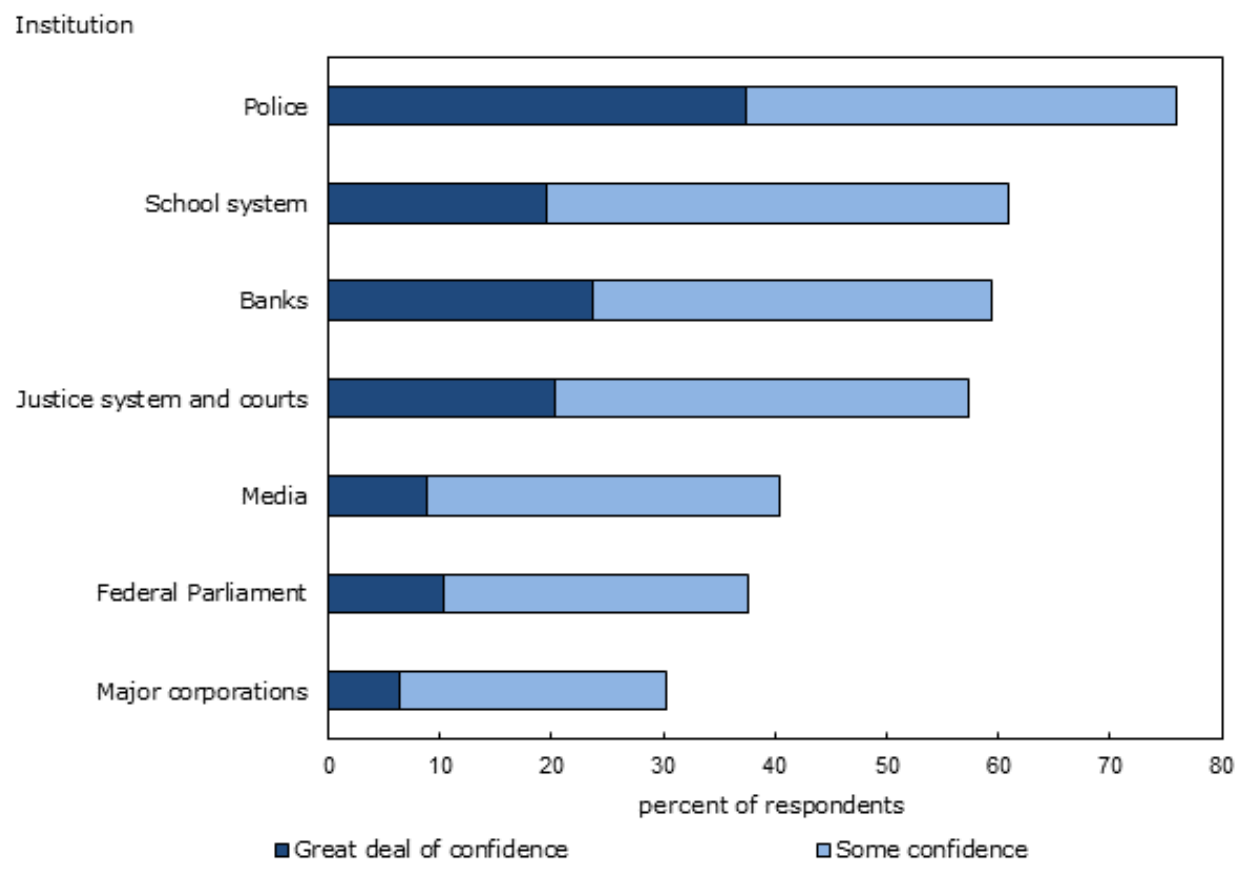

Note: Responses of don't know/not stated are excluded from the calculation of percentages. Source: Statistics Canada, General Social Survey on Social Identity, 2013.

Figure 3. Public Confidence in Canadian Institutions in 2013 (Cotter 2015)

\subsubsection{Perceived Risks and Benefits}

Social trust in authorities is an important aspect of hazardous facility siting. This is because when a member of the public lacks the knowledge to understand the technical aspects of a risk, they tend to perceive that risk with respect to the responsible authority. If they have a low level of trust in the authority managing the risk, they are more likely to judge that risk negatively. Alternatively, people who were knowledgeable about a certain hazardous technology were not influenced by their trust in the responsible authority when judging the risk (Siegrist and Cvetkovich 2000). This theory was tested in a study performed by Siegrist and Cvetkovich at Western Washington University. They asked students to make judgements about the risks and benefits, presented by 25 different technologies and activities. They were also asked to report their knowledge of the technology/activity and their level of trust in the authority that manages the technology/activity. The findings supported the above-mentioned theory, participants with high trust in authority's perceived lower risk and greater benefit associated with a certain technology/activity. This was especially the case for the nuclear, hazardous waste disposal and chemical plant operation industries. It was also found that risk and benefit were inversely related. Using this relationship one can assume that perceived risk can be reduced by increasing the 
benefit. That was not the case in this study, the correlation between risk and benefit became more complex when trust levels were controlled (Siegrist and Cvetkovich 2000).

\subsubsection{Conventional Siting}

The conventional siting method is referred to as a closed siting approach (Kuhn and Ballard 1998). The decision making power lies with the proponent and these decisions are often made with a focus on technical and environmental constraints. Social and political opposition is not taken into consideration until and unless there is a siting conflict.

Conventional siting is carried out using a multi-phase screening process to arrive at the one location that best protects public and environmental health, while meeting all of the facility's technical requirements (LaGrega, et al. 1994). At a high level, these phases are as follows: First, an initial screening of a region is performed to identify areas with the appropriate geographic, economic and technical characteristics that the facility requires. The next step is to identify sites within the areas identified in phase one. The final phase is to perform a detailed evaluation of the sites to arrive at the final site (LaGrega et al. 1994). The last two phases are where the proponent would consult with the municipalities being considered as potential sites. The local community's willingness to host the site is one of the important factors to consider when finalizing a site. Geographic Information Systems (GIS) are useful tools for this siting method (LaGrega et al. 1994). In a GIS software, various maps containing environmental and social land use information can be superimposed on each other in layers. Buffer zones can then be applied to each layer in order to create an exclusion zone around a specific characteristic.

This siting method follows an exclusionary approach. Sites are deemed unacceptable based on a mix of discretionary and compulsory criteria. The site that withstands these exclusionary practices is the final site. This stringent and detailed siting process appears to be extensive enough to satisfy all stakeholders; however, this is not always the case. The criteria used to determine the acceptability of a site are often subjective. Buffer zone limits may or may not adhere to a standard. In cases where no standards exist, it is likely that not all stakeholders will agree on the stated buffer zones, some stakeholders will want limits that are more stringent while others will demand the opposite.

This method is not always used with the intention to discover an ideal site. This method can also be put in practice when a proponent already owns a piece of land where they would like 
the site to be built. In this case, as long as this method proves that the preferred site is safe and satisfies all important criteria, a more superior site is not given serious consideration (LaGrega et al. 1994). In these situations, this method can also be used to justify the acceptability of the preferred site by manipulating buffer zone requirements.

\subsubsection{Cooperative Method}

This method is an example of an open siting process where social and political factors are the focus; this creates a democratic siting process. An open siting process requires communities to volunteer to host the facility. After several volunteer communities express interest, further studies are performed to determine which site is the most environmentally and technically feasible; at the same time, the communities are continually provided with important information to help them make their decision. Communities can opt-out of this process at any time and are considered as partners as long as they are cooperating with the proponent (Kuhn and Ballard, 1998).

This method is significantly more democratic than the previous closed method and, therefore, requires an open dialogue with all potential host communities. This method focuses on reducing and managing perceived risks, having an effective risk communication plan, sharing the benefits and control of the facility. Armour (1992) outlines an effective cooperative siting method using five principles and five safeguards. The purpose of the principles is to help in making a cooperative decision. Similarly, the five safeguards are meant to protect the decision once it has been made.

The first principle of the cooperative siting model is that a host community must volunteer to host the facility, with the option to opt-out before a decision has been made and officiated through a contract. It is expected that the decision will only be made once all interested parties are satisfied with the agreement. To arrive at this possibility, it is important that the proponent keep the host community interested in what they have to offer. This highlights the importance of the next principle, which is to ensure that the host community is fairly compensated for their participation. Compensation is an important part of any siting method and should be paid openly and early on in the project lifecycle. It is also important that compensation is not offered until the community has properly understood the perceived risk they face. The third principle is to treat the community as a partner in the problem, as well as in the solution. If 
the community views the lack of a service as a problem, they will be much more likely to accept a facility that can offer that service. This ties in to the fourth principle, which is to give the community the control to select the technological options available to them that offer the required service, as well as the measures to be taken to manage risk. A community will be less hostile when presented with an array of technological solutions compared to just one solution, even if it happens to be the best one available. The last principle is to assure the community that the site, technological solution and risk management measures will maintain public and environmental health. These five principles, similar to the five safeguards, are generic guidelines and must be applied in any order before a final decision is made (Armour, 1992).

The following five safeguards are meant to prevent disadvantaged communities from being exploited. The first safeguard is to ensure that a clear impact management plan is used and the community is aware of the impact management options available. The second safeguard is to ensure that community members are actively involved with the proponent, not only for technical inspections as well as social and political reasons. The community should draft criteria that technical advisors must meet and propose such advisors from among community members. The federal authority responsible for overseeing the project should then choose technical advisors from this demographic. The third safeguard is to conduct all site and technological assessments together with the proponent, community and technical experts. The community should compose the terms of reference for the environmental assessment to ensure that their prime concerns are considered from the very start of the assessment process. The fourth safeguard is that the community should develop a liaison group that will have as much influence on the municipality's decision as the siting authority. This group will share responsibility with the siting authority to host consultation periods with the public. The final safeguard is that funding has to be provided by the siting authority to ensure that the community can participate in all the safeguards mentioned previously. No community should be deprived of these safeguards due to financial constraints, nor should they be expected to shoulder the cost of any siting activities, aside from legal and alternate study expenses (Armour, 1992). 


\subsection{Siting of Other Nuclear Facilities in Ontario}

\subsubsection{AECL Siting Recommendations}

Geologic storage has been considered the preferred option for nuclear waste storage internationally for several decades (World Nuclear Association 2015). In 1994, Atomic Energy of Canada Limited (AECL) released an Environmental Impact Statement on the Concept for Disposal of Canada's Nuclear Fuel Waste (AECL 1994). A chapter in this statement is dedicated to implementing the deep geologic repository disposal concept. A subsection in this chapter lists principles to be adhered to by the implementing organization and highlights important steps to be taken in the siting process, and characteristics of an ideal site (AECL, 1994).

Five important principles discussed in the report are safety and environmental protection, voluntarism, shared decision-making, openness and fairness. Safety and environmental protection implies that along with obtaining all legally required approvals and licenses, the proponent would do everything possible to minimize adverse effects on human, socio-economic and environmental health. It is also important to continually monitor the facility during operation and for many years after it is closed. Developing emergency response plans is also considered of utmost importance. Voluntarism means that no community will be forced to host a DGR and ultimately it would be the community's decision whether or not they want to host the facility. Shared decision-making is a process that would occur between the proponent and potential host communities as well as other communities (municipalities, local individuals and groups of local individuals) at various stages in the siting process. The proponent would not only consult with the host community but would also seek input from and address concerns of potentially affected communities. Openness means that during the siting process the proponent provides information to the public, not limited to potential host communities. The purpose of this is to provide the public with the resources needed to determine if the project fulfills the requirements of "safety and environmental protection". Fairness means that the previous four principles are adhered to and that the host community is compensated for the service they provide to all other communities that consume electricity generated by nuclear power (AECL 1994).

The chapter breaks down the entire life of the project into seven stages and provides a timeline for each stage. The stages are siting which would last for 20 years, construction for 5 years, operation for another 20 years, pre-decommissioning extended monitoring which would 
be ongoing during operation, decommissioning for 10 years, post-decommissioning extended monitoring which would be ongoing and closure which would take another 2 years. This timeline highlights the importance of a lengthy and detailed siting process, the only stage that is expected to be as long as the operation stage. Within the siting stage, this chapter continues to outline six steps that should be followed to determine the suitable location for such a facility. The first step is to apply exclusion criteria and study available site characteristics to identify siting regions. The second step is to consult with the public to determine which communities may serve as potential hosts. The third step is to consult with each potential host and evaluate the community's exclusion criteria to identify a candidate area. The fourth step is to consult with each candidate area and investigate the surface and boreholes to begin preliminary designs and assessments to determine a candidate site. The fifth step is to perform detailed design and assessments and determine a ranking system for each candidate site. This would lead to the identification of the preferred site. The final step is to confirm the technical suitability of the site and obtain a license to construct the facility at the final disposal site (AECL 1994).

Some characteristics of a candidate area are also outlined in the siting section of this chapter. The site should be located in a regional upland location with low local topographic relief; this would ensure that any released contaminants would travel very slowly from the facility to the surface. In order to minimize the risk of earthquakes, the ideal location should be free of postglacial faulting. The site should be far from both operating and abandoned mines to minimize the possibility of human intervention in the future. The area should cover a large area and contain deep plutonic rock to maximize the possibility of finding a candidate site within the area. In Canada, this type of rock formation can only be found in the Canadian Shield. The plutonic rock should have uniform properties so it may be a predictable barrier to contaminants. The surface should display extensive rock formations to provide additional information on the rock below. The site should not be near any fish spawning grounds to minimize and environmental damage from pre-closure activities. The final characteristic is that the site should be close to the sources of nuclear fuel waste and the resources needed to construct the facility in order to minimize transportation (AECL 1994). 


\subsubsection{Canada's HLW Siting}

The Nuclear Waste Management Organization (NWMO) began the search for a nuclear fuel repository in 2007. The NWMO has been working with various interested communities to define a fair process to identify a willing and informed host community (NWMO, 2010). The next stage is for the interested communities to learn more about the DGR siting process and undergo an initial screening to determine their eligibility for hosting a DGR (NWMO, 2010). Any interested communities that pass the initial screening can continue on to the next stage for a preliminary assessment (NWMO, 2010). At this stage, the NWMO advises interested communities to involve other stakeholders, such as Aboriginal communities, in the siting process (NWMO, 2010). These assessments aim to determine if there is potential for finding a safe site, if the project will promote the well-being of the community, if citizens are likely to remain interested in the project throughout the siting process, and if there is potential to maintain the well-being of the region (NWMO, 2010). The HLW DGR siting process follows an open siting method; it can therefore be expected to face less opposition than if it had followed a closed siting method.

\subsubsection{Low Level Radioactive Waste Siting Task Force}

A siting process task force on low-level radioactive waste disposal was created to suggest the most promising siting process for a LLW disposal facility in Ontario. The task force was to report to the Minister of Forestry and Mines (McTaggart-Cowen et al. 1986). It addressed the lack of universally applied procedures, acknowledged disregard for community concerns by the Atomic Energy Control Board (AECB) and outlined a detailed 5 phase siting process. Siting Process: Establish Guidelines, Regional Information Sessions, Community Information and Consultation, Project Assessment, Implementation. The report also contains a section on siting a LLW storage facility, not limited to a DGR. The report finds that the conflict with facility siting does not lie in scientific or technical issues; the problem is with the method and processes followed to finalize a site. The report then lists a five-staged process of siting a facility. The first stage is to identify the need of a certain facility and what requirements it should meet. The second stage is to identify the technological options for constructing the facility. Third, criteria must be described and ranked by importance to compare different sites. Fourth, elimination criteria must be applied to limit the potential sites. All of the potential sites must then be 
thoroughly assessed and ranked to reveal the ideal site. The final stage is to perform detailed design and study the proposed facility's effects on the environment (McTaggart-Cowen et al. 1986).

Three important outcomes of studying this process help highlight its shortcomings. All three centre on the importance of technical feasibility. The first is that scientific data and costbenefit analyses are the most important evaluating criteria. The second is that the technologyenvironment relationship takes importance over socio-political considerations. The last is that expert involvement in the siting process is much more valuable than public participation. These outcomes imply that traditional facility siting has focused on scientific facts that will lead to solutions that benefit all stakeholders; this approach to siting is being challenged based on various concerns. One such concern is that when siting a facility, many scientific processes rely on assumptions; the validity of these assumptions is questionable considering that they are subjective and made by experts for specific scenarios. Another issue is that it is impossible to predict the nature of public opposition before potential host communities are identified, which is quite late in the siting process. There are also chances that the public will not be in agreement with the evaluation criteria and trade-off decisions made by the experts. The most important issue with this process is that this structure follows a top-down approach, which will inevitably make the public feel as if a decision is being imposed on them. A top-down approach is one where a governing organization makes a decision, then afterwards lower level managers provide their input, and finally the public's opinion is heard. This is opposite to a bottom-up approach where the public is involved in the decision making from the beginning and the decision works its way up to the governing organization (McTaggart-Cowen et al. 1986).

The underlying issue of facility siting is the public opinion that social concerns are not taken into consideration in the traditional siting process. Five key factors have been identified that highlight public concerns. The first is perceived risks. Experts and the general public both perceive risk as the product of the probability of an event and the magnitude of the consequences of that event. The way they assess this risk can vary dramatically from person to person. The general public tend to focus on the consequences while experts focus on the probability. The second issue is that of iniquity and stigma. When a community is chosen as the host site, they are essentially chosen to bear the burden of a facility for themselves, as well as for the broader public. The third issue is centred on compensation; it is important that they are compensated for 
any adverse effects the facility may have on their lifestyle or their property value. Loss of control is another issue that fuels opposition from residents. This results in the proponent having to justify their decision and the public growing increasingly resistant. Political intervention is often necessary in this case, which further alienates the public. The final issue is the lack of trust towards the nuclear energy industry. The two most important factors are iniquity and loss of control. If the public feels that they will be compensated for any hardship and have some influence on the final decision, many of the other concerns can be effectively addressed (McTaggart-Cowen et al. 1986).

The report recommends that the AECB write a set of safety standards, which can be applied to all licenses in order to eliminate debates in the siting process. Additionally it recommends that the siting process should shift its focus from technocratic to collaborative problem solving (McTaggart-Cowen et al. 1986).

\section{Methods}

This research paper presents an in depth case study for the purpose of understanding why there has been significant opposition against the approval of the DGR license in Kincardine Ontario. This will be determined by an inductive analysis of qualitative data. This paper will suggest steps moving forward that may mitigate some of this opposition. These suggestions will be the result of lesson drawing from similar siting procedures.

A primarily qualitative research approach was taken to complete this study. Quantitative data was incorporated into the study to support qualitative statements where such data was available and relevant. Qualitative research was performed in the form of case studies focussing on the Kincardine DGR. The case study tactics that were applied in this report are pattern matching and explanation building. These tactics were applied to infer the cause of opposition and how it could have been prevented. These tactics are a form of inductive content analysis. They were used to draw a link between OPGs siting process and patterns present in the siting methods from Section 2.5. Pattern matching is a method of qualitative data analysis used in case study research to where conclusions for an empirical case are drawn from predicted or empirical alternatives (Yin 1984). In this paper the empirical case is the OPG DGR, the predicted alternatives are the guidelines from AECL, the Low Level Radioactive Waste Siting Task Force and the empirical alternative is the NWMO siting process for a HLW DGR. These alternatives were selected due to 
their spatial, temporal or technical similarities with the empirical case. Content analysis is a more generic research method where logical and valid results are drawn from interpreting qualitative data. Inductive analysis is used to study qualitative data when previous theoretical content is limited. In this case the limitation is that there is no source that focuses on the siting of a L\&ILW DGR. There are only sources for HLW and LLW DGRs. Therefore, an inference has to be made to apply these sources to this case of a L\&ILW DGR. This is unlike a deductive approach where an existing theory is tested by applying it to a specific case (Elo and Kyungas, 2007).

The two sources of evidence that are presented in the paper are documentation and archival records. Research was gathered using various sources of data such as publicly available documents (reports, assessments, journal articles, news articles, etc.) and audio-visual information (public hearing videos), refer to Table 3 for more information. In order to ensure the validity of the data collected, the majority of the case specific information was obtained through credible sources such as OPG, NWMO, and AECL. Much of the general information in the literature review was retrieved from peer reviewed journal articles. Once the data was collected, important aspects of hazardous facility siting discussed in the literature review were applied to the case study. The aspects are community engagement, perceived risk, trust in authorities and compensation. The DGR siting process was also compared to the predefined siting guidelines listed in the literature review. Any variances between the guidelines and the siting process of the Kincardine DGR were highlighted and discussed. The purpose is to determine why the variance exists and what effect it had on the siting process.

Table 3. Information sources

\begin{tabular}{|c|c|}
\hline Organization & Documents \\
\hline OPG & $\begin{array}{c}\text { Records, reports, brochures, fact sheets, FAQs, press releases, } \\
\text { official statements, contractor reports, contracts, project reports }\end{array}$ \\
\hline NWMO & Project siting plans, annual reports \\
\hline AECL & Guildine report \\
\hline CEAA & Acts \& laws, environmental assessment \\
\hline CNSC & Public hearing videos \& transcripts, acts \& laws \\
\hline SON & Environmental office reports \\
\hline ENV. GROUPS & Resolutions, \\
\hline CELA & Open letter \\
\hline US GOVERNMENT & Open letters \\
\hline LOCAL MEDIA & News articles \\
\hline ACADEMICS & Peer reviewed journal articles, expert reports \\
\hline
\end{tabular}


The Figure 4 and the following paragraphs outline the steps that were taken in order to achieve the research objectives and answer the research questions:

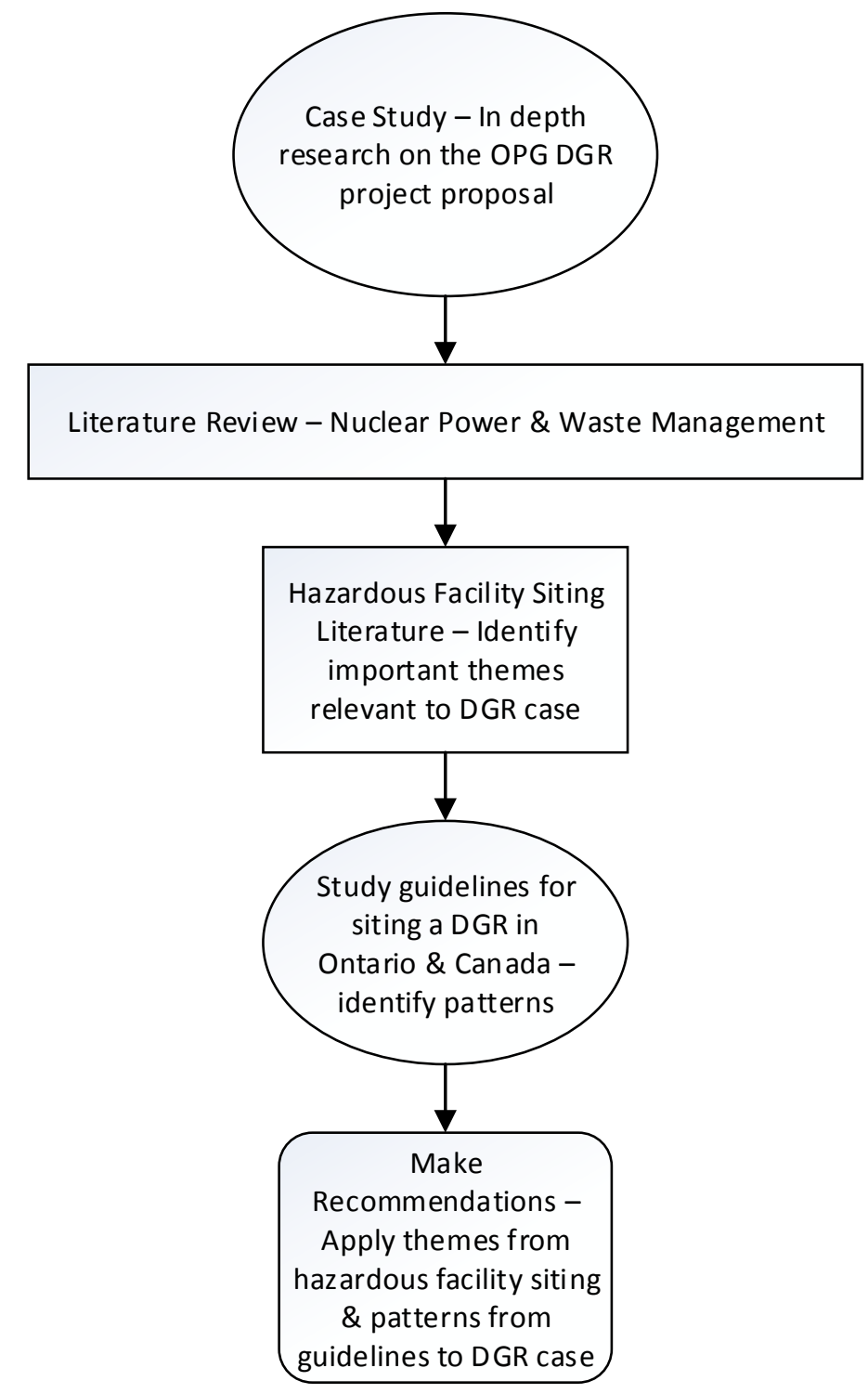

\section{Figure 4. Research Method}

The first step was to study the case in depth. There are two important aspects of the case that were focused on in this study. One was the process OPG followed to determine that Kincardine, Ontario is the preferred location for a L\&ILW facility. The second was the sentiments of stakeholders regarding the project site. This was achieved by studying publically available primary sources in the form of reports, assessments, journal articles, news articles and videos from public hearings. 
The next step was to perform the literature review, starting with the broad subject of nuclear power and nuclear waste management. This was to assist in understanding the public perception of the industry and provide generic information related to the case.

The third step was to study hazardous facility siting literature, to identify important themes in hazardous facility siting. These themes were applied to the DGR case to draw conclusions about the cause of opposition. These themes are explored once again when making recommendations on how the opposition can be minimized.

The fourth step was to study hazardous facility siting methods specific to DGRs in Ontario and Canada. The main purpose was to determine what process should be followed when siting a DGR for any type of nuclear waste (HLW, ILW and LLW) in Ontario. This was done by studying guidelines suggested by AECL, the NWMO of Ontario and the Siting Process Task Force on Low-Level Radioactive Waste Disposal (1986). Patterns in these three siting processes were found. Process phases that were common among all three were compiled to create a recommended siting process for the Kincardine DGR. This helped to identify crucial steps that were omitted in the siting process of the Kincardine DGR.

The final step was to make recommendations on how to proceed with the project and how to avoid similar mistakes in future with other similar projects.

A limitation of this method is data was gathered from one main information source: documents and archives. Gathering data from various information sources would assist in strengthening the credibility of the results. Data gathered from interviews with important stakeholders would be of value.

\section{Case Study Findings}

\subsection{Proponent - OPG}

In Ontario, OPG produces nuclear power in Pickering and Darlington and Bruce Power operates the nuclear generating station in Tiverton. In 2015, Ontario's nuclear reactors generated $60 \%, 92.3 \mathrm{TWh}$, of the provinces total energy consumption, greater than any other fuel source (Independent Electricity System Operator 2016). The units also generate a significant amount of nuclear waste. An inventory summary report produced by the Low-Level Radioactive Waste Management Office indicated that by the end of 2013 the following volumes of nuclear waste 
had been produced in Ontario: 2.352 million $\mathrm{m}^{3}$ of LLW, 34, $770 \mathrm{~m}^{3}$ of ILW and 10, $021 \mathrm{~m}^{3}$ of HLW (2013). The LLW generated in Ontario has been safely stored at the Western Waste Management Facility in Bruce County for the past 40 years (OPG 2016); however, above ground storage is not the ideal method of long-term nuclear waste storage. This is why OPG is proposing to store L\&ILW in a DGR at the Bruce Site in Kincardine, Ontario.

\subsection{Regulators}

\subsubsection{Canadian Environmental Assessment Agency (CEAA)}

The Canadian Environmental Assessment Agency (CEAA) regulates EAs in Canada. An EA is necessary when a project is considered to have the potential to cause significant adverse effects. If this is the case, proponents are encouraged to initiate the EA process as early on in the project planning stages as possible. This is so that the proponent can consider the results of the EA in their proposal and incorporate mitigation methods to their project plan (CEAA 2015). A review panel is required to carry out the EA when the Minister of Environment believes that it is in the public's best interest. This is determined using the following three factors: the project may cause significant adverse environmental effects, the public has an interest in the project and its potential environmental effects and more than one jurisdiction plays a role in the assessment of the project or a part of the project (CEAA 2015). In this case study, the CEAA referred the EA to a three member review panel.

\subsubsection{Joint Review Panel}

The EA report was prepared by a joint review panel (JRP) consisting of the following members: Dr. Stella Swanson (Chair), Dr. James F. Archibald and Dr. Gunter Muecke (Swanson et al. 2015). Dr. Swanson has worked at all levels of government in various industries. She completed her post doctorate fellowship in Radiation Ecology at the Saskatchewan Research Council. Dr. Archibald is a professor from the Department of Mining at Queen`s University. Dr. Muecke has worked with both the federal and provincial government Canada as well as with international organizations; he was a consultant for the Hahn-Meitner Institute of Nuclear Studies, Berlin, Germany. All three panel members are temporary commission members for the CNSC (Canadian Nuclear Safety Commission 2016). Several other team members were involved in the EA process consisting of three members from the CEAA and five from the CNSC (Swanson et al. 2015). All three panel members are now members of the CNSC; this could 
possibly create a bias towards project approval. A more varied panel would provide a broader perspective on the project.

\subsubsection{CNSC}

The Canadian Nuclear Safety Commission (CNSC) is the responsible authority for all aspects of the nuclear industry. Their mandate is to prevent the nuclear industry from degrading human and environmental health while maintaining safety and security (CNSC 2016). Another aspect of their mandate is to ensure that nuclear energy in Canada complies with international safety standards and commitments. The CNSC also provides the public with objective technical information about the industry. The CNSC consists of permanent and temporary commission members who make decisions that impact the industry, as well as over 800 employees working for the commission (CNSC 2016). The CNSC was established in 2000 and reports to the Minister of Natural Resources. The commission replaced the AECB which managed nationwide nuclear affairs from 1946-2000 (CNSC 2016).

\subsection{Opponents}

Opponents of the DGR have raised several objections to the project. The objections and critiques that should be given the most importance are those that are voiced by multiple opponents and supported by EA experts. Some common objections between opponents refer to uneven risk and wealth distribution, proximity to the Great Lakes, the lack of a structured siting process, poor mitigations strategies and weak cumulative effects assessment. Some opponents have specific concerns in addition to shared concerns. The Aboriginal community demands that they be included in the regulatory process of waste management and that OPG recognizes the value of traditional ecological knowledge, knowledge that is unique to Aboriginal people (CEAA 2016). Objections raised by the international community highlight the need for boundary organizations and strong intergovernmental environmental relations. The following sub-sections highlight these concerns in detail.

\subsubsection{Aboriginals}

The Saugeen Ojibway Nation (SON) was not consulted when the nuclear industry first began operations in their territory in the 1960s. It was only in the early 2000s that SON started pressuring the nuclear industry to recognize their rights; including the right to be involved in the 
management of nuclear waste (Saugeen Ojibway Nation Environment Office 2015). Since then OPG has been working to mitigate the objections raised by the SON and other surrounding aboriginal communities. If OPG had included SON in the regulatory process at the same time as the other communities they engaged, there would be much less hostility felt by the community. One must keep in mind that in order to effectively participate in environmental planning decisions, citizens must represent society as a whole and not focus on self-interest (Fischer, 2009). The problem with the other communities that are engaged in the process is that they have much to gain from the project financially. The other issue is that of indigenous knowledge, which is gaining credibility all over the world (McGregor, 2004). The Canadian Environmental Assessment Act, 2012, references a guide for considering Aboriginal traditional knowledge in an EA. The guide discusses the importance of traditional knowledge and includes principles for implementing it in an EA (CEAA 2012). This is because indigenous people are known to have a strong relationship with the environment and often work in collaboration with the government on projects effecting the land. Indigenous knowledge may not have been considered valuable to the field of nuclear waste management since it was never a problem in indigenous history. Despite this disconnection to nuclear waste, the rights of the Aboriginal communities must be respected and their knowledge of the land must be taken seriously. One important lesson to learn from indigenous knowledge is that "all of Creation is important; all must be respected" (McGregor, 2004). The Earth as a whole should be viewed as a valuable creation, including the underground bedrock that upholds the surface.

\subsubsection{International Stakeholders}

Five US Senators and twenty-six US representatives wrote to Prime Minister Trudeau with a request to reject the DGR proposal (CELA 2015). The international community has expressed concern over the DGR location, since it is located in the Great Lakes Basin where the International Joint Commission (IJC) manages environmental concerns. The IJC consists of three Canadian and three American commissioners. The commission employs scientists and support staff that to protect the Great Lakes. Concerns from international opponents can be amplified if voiced through the IJC. Where there is the absence of a transboundary organization, conveying environmental concerns across a border is a challenging task. 
Kincardine has been profiting and will continue to profit from the project, not only in financial payments but also in the form of job creation. The entire Province of Ontario will benefit from nuclear power production. Communities on the other side of the border will only receive risk without the benefit. Michigan State, Oregon City and St. Clair County are not generating electricity through nuclear power; this makes it unreasonable to expect them to face any risks when it comes to nuclear waste management. Policy planning varies drastically from one region to another; the variations between two countries can be significant. The Great Lakes Basin is the largest trans-boundary water basins in the world, management and governance of this region faces multilevel challenges (Johns, 2009). Candice Miller, a member of congress in the United States, wrote to the Secretary of State, John Kerry, requesting the federal government to involve the IJC in this project. If the IJC gets involved with the project, the DGR might face many new hurdles towards earning approval. The IJC would have no trouble in having their voice heard, as they are a boundary organization that monitors pollution in the Great Lakes Basin, including radioactive contaminants (International Joint Commission, 1997).

Citizens have very high expectations of boundary organizations, these organizations are meant to merge the fields of science and policy by working towards the common good of all stakeholders and base this work off unbiased decisions. There is no defined boundary organization involved in the DGR project, the IJC is not currently involved and the JRP cannot be defined as an organization. The main purpose of the JRP is to mitigate the environmental assessment process through complexities that may be encountered when more than one level of government is involved (e.g. federal and provincial or another jurisdiction) (Canadian Environmental Assessment Agency, 2015). The Nuclear Waste Management Organization would appear to be a boundary organization. The NWMO would appear to be a third party organization that has the sole objective of effectively managing nuclear waste with no affiliation to neither proponents nor opponents of the nuclear industry. In reality the NWMO does have a bias towards the nuclear industry because it is an organization that was jointly created by OPG, New Brunswick Power Corporation, Hydro-Quebec and AECL in 2002 (CNSC 2016). These four organizations are responsible for funding the NWMO. As of December 2015 the organization's trust fund balance was $\$ 3,729$ of which $\$ 3,412$ was paid by OPG (NWMO 2016). OPG has contracted the NWMO to handle the DGR approval project on their behalf in 2009 (NWMO 2015). The NWMO fits the definition of a boundary organization that merges the 
realms of policy and science (Guston, 2001). Despite being a boundary organization, the NWMO has a clear bias towards OPG's agenda.

\subsubsection{Environmental Organizations}

The Canadian Environmental Law Association (CELA) wrote a letter to Minister Catherine McKenna requesting her to reject the Kincardine DGR proposal. Sixty-seven Organizations signed this letter including Greenpeace US, Sierra Club US and Sierra Club Canada and various local organizations spanning from Ohio, to Algonquin to Connecticut (CELA 2015). Stop the Great Lakes Nuclear Dump is a citizen organization that was formed for the sole purpose of opposing the DGR project. The organization marked all the counties that have passed a resolution against the DGR on a map, refer to Figure 1 in Section 1.2 of this report. The figure shows that 186 communities in the Great Lakes Basin are opposed to the project.

\subsection{Timeline}

Any major decision should be made only after spending a significant amount of resources to determine the right course of action. The amount of time and money required to make a sound decision is proportional to the complexity of the project. The LLW DGR project is a technically complex undertaking that involves a multitude of stakeholders. In order to ensure that important technical and stakeholder requirements are met, the DGR project is undergoing a lengthy approval process, which is outlined below:

OPG DGR Timeline the CNSC (Nash 2005).

January 2006

June 2007

April 2008
The CNSC posted a notice of EA.

EA was referred to a JRP.

The CNSC and the CEAA drafted guidelines for the environmental impact assessment and the JRP agreement. 
April - June 2008

January 2009

April 2011

February 2013

March 2012 - May 2014

April - May 2013

June 2013

September - October 2013

September 2014

November 2014

May 2015

September 2015

February 2016
The CNSC made this draft available for public review and comment.

The CNSC and the CEAA finalized the environmental impact assessment and JPR agreement.

OPG submitted the environmental impact assessment and the documentation for the license for site preparation and construction to the JRP.

The JRP held an internal orientation session, comment period and review of the documents submitted and announced the public review period.

The JRP requested additional information from OPG or the CNSC 13 times.

The JRP announced that the public may comment on the environmental impact assessment and license request.

The JRP announced that they would hold public hearings later that year.

Public Hearings.

Another set of public hearings were held by the JRP.

The JRP closed the record for the EA.

The JRP submitted the EA report to the federal Minister of the Environment (CNSC 2015).

The Minister of Environment was expected to approve or reject the project based on the information provided in the EA four months after receiving the report. The decision was postponed several times, also due to the federal elections in October 2015.

The Minister of Environment, Catherine McKenna, requested OPG to make the following three changes to the EA: consider alternate 
sites, detailed cumulative environmental effects assessment and updated mitigation measures for each adverse effect (CNSC 2016).

If the project is approved, the JRP will issue OPG with a license to prepare site and construct (CNSC 2015). The EA process extended over a period of nine years and consisted of a total of 33 days of public hearings over a two-year span in 2013 and 2014 (OPG 2016). The 2013 program for public hearings allotted time for opening remarks from the JRP chair, a presentation by OPG, a presentation by the CNSC and presentations only by registered presenters including Aboriginals scheduled where appropriate (CEAA 2013). Several of the participants expressed concern over the lack of detailed mitigation efforts and cumulative effects analysis (CEAA 2014). Their concerns were clearly valid and not addressed effectively since the Minister of Environment echoed those critiques.

\subsection{Environmental Assessment}

\subsubsection{Requirements}

In the case of OPG's proposed DGR, the facility is a first of its kind in the country. Therefore, the potential effects are unknown; erring on the side of caution, the EA must consider possible adverse effects in the event of an operational accident or failure. The EA must then state the significance of those effects on the environment. The general public has a stake in the project because it is located in a water basin that millions of people rely on as a water source. Due to the site being located in the Great Lakes Basin, multiple jurisdictions identify as stakeholders; including some from the other side of the border. The Oregon City Council drafted a resolution opposing the Kincardine DGR stating that 3 million Ohioans depend on Lake Erie, which receives most of its water from Lake Huron, for drinking water (Bihn 2013). Copies of this resolution were sent to Premier Kathleen Wynn, Michael Binder, president and CEO of the CNSC, Governor John Kasich and Lake Erie Basin state and federal elected officials. Various other officials have formally opposed the DGR construction such as the Michigan State Senator, Hopgood, the St. Clair County Water Quality Board, Hayes, and the City of Marine City, Lepley (CEAA 2016).

The term environment is broken down into the following categories in this EA. The natural environment includes impacts on soil quality, air quality, noise and vibration, surface water and near-surface groundwater, plants, animals and their habitats. The assessment has a 
separate section focussing entirely on Lake Huron and the Great Lakes. It also comments on human health assessment, Aboriginal interests, social and economic aspects and discussed potential malfunctions, accidents and malevolent acts (Swanson et al. 2015). A more detailed discussion of these impact areas will be provided in the following section.

\subsubsection{Summary}

Soil: The soil quality is not expected to degrade significantly through indirect sources. Direct impacts on soil quality may stem from the removal of soil, the operation of a new storm water management system and seepage from the waste rock containment area. The waste rock, estimated to be about 1 million $\mathrm{m}^{3}$, produced from the extraction process would be managed on site. Another additional management feature that would need to be operational for the project is a new storm water pond. The title of this pond is misleading as it will treat not only storm water but also saline groundwater pumped up from the excavation site. Once suspended solids are removed from the wastewater, the remaining water will infiltrate into the existing Bruce nuclear drainage network and ultimately flow into Lake Huron. The pond will be designed to successfully manage excess water from a significant storm event such as a six hour, $25 \mathrm{~mm}$ rain event (Swanson et al. 2015).

Air: To assess air quality, OPG used conservative assumptions to create a model in AERMOD, which is a standard air quality modelling software used in Ontario. The assumptions were that vehicle and equipment emissions, noise and dust sources would be in operation all at once and around the clock. Other model inputs included five years' worth of meteorological data from the site. The results of the model are not mentioned in the assessment; however, $\mathrm{PM}_{10}$ and $\mathrm{PM}_{2.5}$ are expected to exceed limits $0.5 \%$ of the time during the construction phase. To mitigate impacts, equipment used in construction must be in good condition and will meet Tier 2 emission standards. Further detail is not provided about this standard anywhere in the report such as who created it, what are the requirements to meet this standard, etc. Vehicles will also abide by new emission standards. Dust will be supressed by the watering of roadways, there is no mention of the runoff associated with this mitigation measure (Swanson et al. 2015).

Noise: Noise conditions were modelled in a software called CadnaA, which adheres to an ISO standard on acoustics. The model uses three strategically placed noise receptors and conservative estimates. Noise is expected to be generated from the various heavy machinery that 
the project will require such as exhaust fans, bulldozers, excavators and others. It is assumed that all the noise sources are upwind of the receptors and that noise levels will be expected to cause an adverse effect if there is an increase greater than $3 \mathrm{~dB}$ above current quietest levels. The report does not state by how many decibels the noise levels are expected to increase. Some mitigation measures mentioned are to plant trees on the waste rock pile to assist in dampening sound waves, the use of silencers, constricting travel pathways and maintaining fans (Swanson et al. 2015).

Impact Area: The impact area of the greatest focus is surface water and near surface groundwater, OPG has identified surface water and near surface ground water as the most likely pathway for contamination of both radioactive and non-radioactive contaminants. The main sources of contaminated water would be groundwater pumped out of the excavation site during construction, runoff from the site during all phases, runoff from the waste rock material as well as potential accidental spills. The site has an extensive pre-existing storm water management system that is capable of handling the excess water resulting from the DGR operations. Near surface groundwater is considered isolated from deep ground water. Boreholes indicate that the potable groundwater in shallow rock, from glacial deposits, only extends $168 \mathrm{~m}$ deep and has no interaction with saline groundwater deeper in the bedrock. The entire site contains a thick layer of clay/silt till of low permeability, this layer is expected to restrict water movement in all directions. The infiltration rate to surface waters is expected to be $5-10 \mathrm{~cm} /$ year. The various contaminant sources to surface water include the saline groundwater pumped up from the ground, nitrates from explosives used in construction, oil from fuel spills, runoff from the construction site and leachate from waste rock that will be acidic, metallic, and saline and also contain nitrates and hydrocarbons. These characteristics were determined by studying a small sample of waste rock. Environment Canada criticised that the assumptions made by OPG cannot be justified due to limited information. For the case of storm water runoff, concerns have been raised about the storm water management systems capability to accommodate increased rainfall events due to climate change in the future. To ease these concerns OPG stated that the system could be expanded if the need arises. Health Canada did an evaluation of the possible effects on drinking water and found that there will be no changes to the drinking water of nearby residents (Swanson et al. 2015). 
Plants: Impacts on various plants, terrestrial animals and aquatic animals were addressed in the report. About 9 hectares of mixed forest and 22 hectares of industrial barren vegetation would be removed in the construction process. Effects were evaluated on eastern white cedar (which may be sensitive to greenhouse gas emissions), heal-all and common cattail (which are adaptive to extreme altering flow conditions). A timeline for monitoring was not provided nor was there any discussion on the possibility of invasive species taking root in the area. Mitigation measures include revegetation on the waste rock pile to minimize habitat loss. Terrestrial species that will be effected include muskrat, white tailed deer, northern leopard frog, midland painted turtle and various birds. Effects on these animals are expected to be minimal, therefore, no significance assessment was performed. Aquatic animals such as small mouth bass, brook trout, benthic invertebrates and others will be subject to some habitat loss. More stringent water quality mitigation measures must be put into place to ensure the protection of aquatic life (Swanson et al. 2015).

Natural Disasters: Along with impacts on the natural environment, the report also addressed the impact of natural disasters on the project such as seismic activity, flooding and severe weather. Any reasonably foreseeable events would not have a significant impact. A human health assessment indicated that with appropriate mitigation measures, the project would have no significant adverse effects on worker or public health. A similar conclusion was made concerning the effects of malfunctions, accidents and malevolent acts. Changes to the biophysical environment will also not be significant enough to have adverse socio-economic impacts. No significant assessment of cumulative effects was performed because no residual effects are expected from the project or any reasonably foreseeable future projects (Swanson et al. 2015).

Criticism: The scope of the EA was appropriate; the report was successful in covering all the potentially impacted aspects of the environment. OPG also made good use of standard guidelines and software for their modelling methods. One critique is that the depth of the study in some areas is shallow, significance assessment is absent throughout the report on the basis that adverse effects are not expected. The panel recommends in various sections of the report that baseline monitoring must be a point of focus to develop effective monitoring programs (Swanson et al. 2015). It is also important that the EA expands the cumulative effects assessment section of the report. There is a possibility of a HLW DGR being sited in the Great Lakes watershed which 
should be considered in the cumulative effects assessment but was not. Finally, as an alternative to constructing the DGR, OPG should have included a section to outline the implications of not building.

\subsection{Siting Process Comparison}

The siting of a hazardous facility is a challenging task. To overcome this challenge, proponents are recommended to outline a structured siting process during the projects inception. The success of the project depends on many different factors. These factors are all determined by how local citizens respond to the project. The project siting process is the stage when the proponent ensures that local citizens are willing to accept the proposed facility. The host community is the most important group of citizens to consult with because they are also the most likely to oppose the facility. Importance should then be given to any nearby communities that may oppose the facility.

The process OPG followed ensured that the host community of Kincardine is in full support of the facility. Opposition to the Kincardine DGR came from various communities in the Great Lakes Basin. The radius of opposition for the Kincardine DGR was larger because of Lake Huron. If this same facility was proposed away from a major body of water, opposition would be raised within a smaller radius. This is for two reasons. One is that if a body of water is contaminated, remediation is much more challenging than remediation of land contamination. The other reason is that large bodies of water are capable of supporting more life than dry regions. The Great Lakes Basin supports a population of 39 million people, 11 million of those are Canadian. These 11 million Canadians account for one third of the countries population. Any threat to so large a population will draw attention an inevitably opposition.

The ideal method to deal with this opposition would be to follow a cooperative siting process. A cooperative siting process would have provided the broader public with various opportunities to voice their opinions and concerns at public information sessions. OPGs process focussed these information sessions on the host and adjacent communities. The following two figures illustrate process maps for both OPGs siting method and a cooperative siting method for a DGR. 


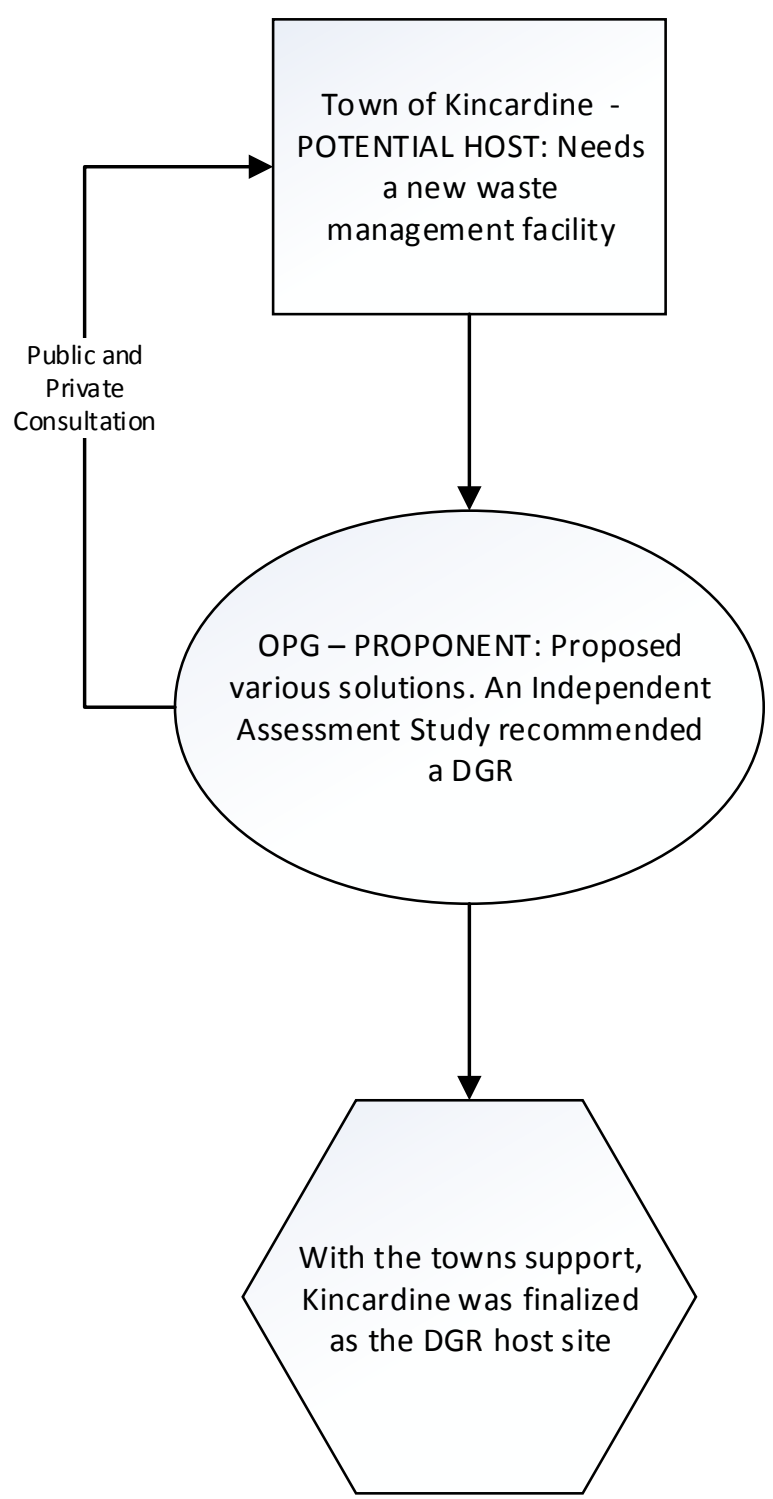

Figure 5. OPG's Siting Process 


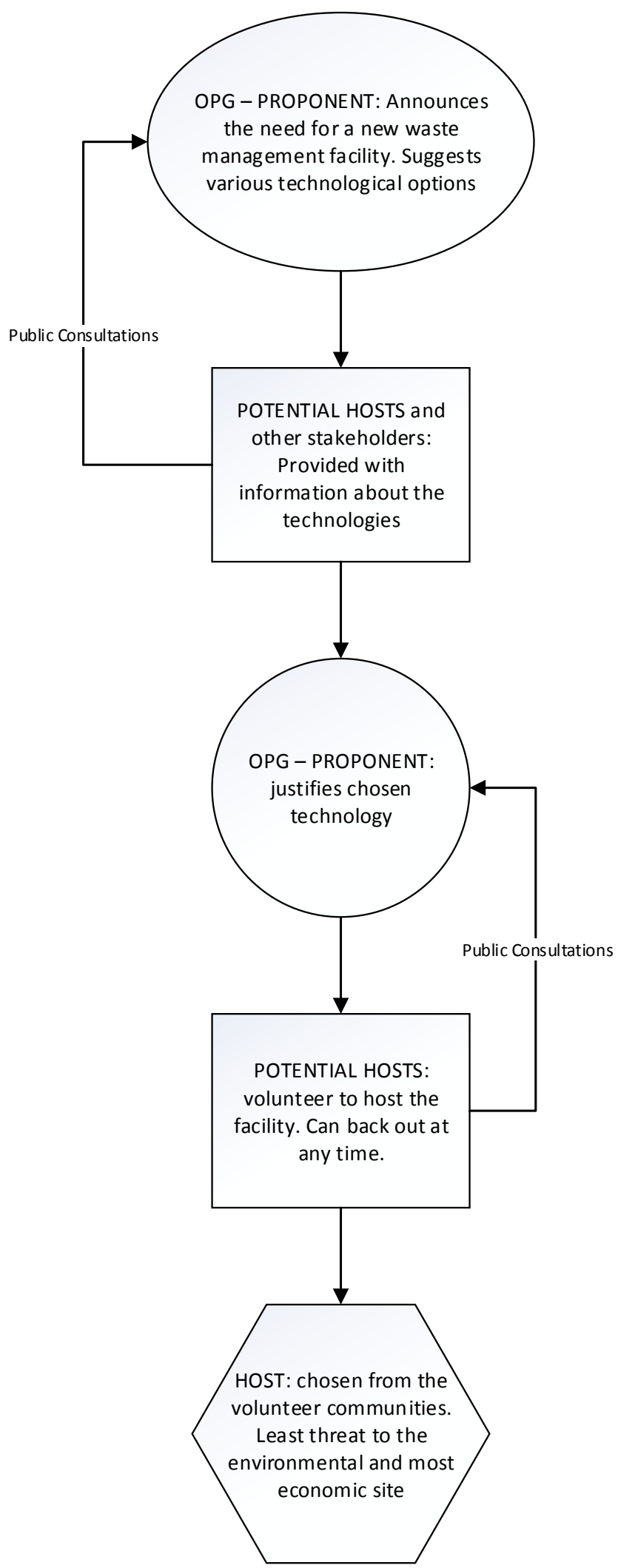

Figure 6. A Cooperative Siting Process Applied to OPG's DGR 


\subsection{Key Factors}

\subsubsection{Lack of Trust}

The DGR idea evolved into a proposal at a time when Canadians had elected a conservative government. The conservative government was in power for a decade. With actions such as withdrawing from the Kyoto Protocol, seriously modifying the Canadian Environmental Assessment Act and placing restrictions on Environment Canada, the Ministry of Natural Resources Canada and the Department of Fisheries and Oceans, the Harper Government became infamous for their disinterest in environmental protection. As mentioned earlier in the report, only 10\% of Canadians placed a great amount of trust in the federal government in 2013 (Cotter 2015). Trust in the federal government has seen a significant increase since the Liberals came into power in 2015. A poll conducted by EKOS Research in April 2016 found that $44 \%$ of Canadians place their trust in the Trudeau government "almost always" or "most of the time" (Connolly 2016). Minister McKenna's request for additional information may have assisted in easing opposition concerns surrounding the DGR. She echoed several of the comments made by concerned stakeholders during the public hearings. Concerns voiced in the hearings surrounding mitigation measures, cumulative effects and alternate sites were reinforced by the Minister. This intervention by the new government may have assisted the project. When stakeholders see that the authority with the power to reject the proposal shares their concerns, they are more likely to be accepting of their decision making process.

While there may be some improvement on the political side of this project, OPG experienced a serious technical hiccough while justifying the safety of their proposed repository. OPG created a conceptual and a computer model. The purpose of the model was to ensure that the DGR design would not create adverse effects on environmental and human health. This was achieved by creating a conceptual model of various scenarios that were then translated into calculation cases. Model data was gathered and entered into mathematical models that were based on the calculation cases. The computer model is a simple compilation of these mathematical models that were solved in a software tool. The purpose of the model was to determine the effects of the DGR post-closure phase. The following three indicators were used to quantify the effect: radiation doses to humans, environmental contamination of radionuclides and 
non-radioactive substances and spatial movement and concentration of contaminants (Swanson et al. 2015).

Shortly after the first public hearing session, Dr. Frank Greening, a retired OPG research scientist and chemist, noticed an error in the calculations used to model the safety of the DGR. His 30 years at OPG deemed him a specialist in his field of work, which was to study pressure tubes in the reactor. Pressure tubes are categorized as ILW and will be stored in the DGR if it is constructed and operational. He noticed that the pressure tube radioactivity was lower than true values by a factor of 2300 (Goetz, 2014). He communicated his findings with OPG and it was determined that his concerns were valid; OPG accepted that they had severely underestimated the radioactivity of pressure tubes in their computer model. They reprocessed the model and due to the high factor of safety included in the model, a redesign was not necessary. While it is a comfort to know that there is a very high factor of safety included in the design, it is worrisome to note that there may be many other errors with the model. Dr. Greening correctly identified one of these errors because he was a specialist in the area of pressure tubes. Assumptions about other reactor components that have not been studied by specialists may continue to be erroneous. Dr. Peter Duinker, a professor of environmental and resource studies at Dalhousie University, raised another technical issue. He was contracted by the JRP as an expert to interpret scientific issues. He identified logical errors committed by the proponent and environmental consultants though the results cannot be deemed entirely incorrect. Many of the values that were set in the model are unjustified and arbitrary. When considering cumulative effects, OPG stated that there must be evidence of a residual adverse effect before considering any cumulative effects. In EA literature, this is a valid, and flawed, statement (Duinker, 2013). Prevention should be a first resort and remediation a last resort. Complexities and interconnectedness in the environment is widespread and it is extremely difficult to predict the environmental impacts of a project. This uncertainty must be addressed with a detailed environmental impact mitigation plan.

Another reason for lack of trust is that citizens are suspicious of the volume of ILW to be stored at the facility. As mentioned earlier, LLW does not need a high degree of shielding and can even be stored in shallow trenches. ILW being stored in the DGR is the main design constraint and cause for public opposition. OPG must acknowledge this and focus on ILW management methods to reassure the public regarding the projects safety. OPG can propose a variety of alternatives for ILW. One such alternative is to store only LLW in the DGR during the 
first few years of operation. ILW should not be placed in the DGR until it is proven safe and a more accurate model is created. Once the facility is proven safe for LLW, the proponent will have concrete results from which to derive their safety claims. The majority of the volume of waste is comprised of LLW; therefore, this should not cause a significant setback to the initial project plan. There is also the possibility that a HLW DGR location will be finalized shortly after the Kincardine DGR. The HLW DGR can store ILW should the need arise since it will be overdesigned for ILW. For this purpose, it is also very important to clearly define an activity concentration level for ILW. The public will be less fearful of ILW being stored in the L\&ILW repository if they have more information about it. If the public, in agreement with the proponent and experts, think that certain ILW have too high of an activity concentration level, they can propose to store it in the HLW DGR.

\subsubsection{Risk Perception}

The opposition that OPG is facing from the public can be viewed as an issue of risk perception. While there is some risk associated with nuclear power plants, often times this risk is perceived to be much higher than it really is. If the public views a certain issue as dangerous, even if there is no grounds for their concerns, the issue must be addressed through effective risk communication. Until society has accepted the risk associated with nuclear energy, all nuclear projects face a social risk, even if they do not face a technical one. Proponents for nuclear energy in Ontario argue that the large-scale release of radioactive contaminants is unlikely and not a concern as long as proper operational protocols are followed. Ontario does not experience strong earthquakes and tsunamis, nor have there been any significant nuclear accidents with commercial CANDU reactors. This is a fair argument, safe operation of nuclear power plants is not a new concern; OPG has always safely operated their reactors. However, until a solution is agreed upon, there will be serious concern surrounding the nuclear waste management processes.

Those opposing the DGR believe that OPG should continue to store waste above ground. What they may not realize is that the Great Lakes region has been facing a risk presented by nuclear waste for the past 40 years. Nuclear waste has been present at the proposed DGR site for four decades; therefore, it is safe to assume that the opposition is directed to the DGR technology more than the nuclear waste. The host community and nearby communities that 
are in support of the facility see the DGR as a risk reduction method while the nearby communities see it as a new risk. One reason for this perception is that the nearby communities are much more involved with the nuclear industry than the opposition groups are. Many of the residents of Kincardine likely work in the nuclear industry that leads them to having a strong understanding of the hazards that nuclear power and nuclear waste present. If they are not employed in the nuclear industry, they have friends or neighbours that are. These residents may have been the first community to learn of the project. This means that the information they receive regarding the DGR project comes from a trusted source. They also have the knowledge needed to understand the technical aspects of this project.

The general public does not possess a deep understanding of nuclear technology and the hazards it poses. If they do not live in a nuclear power plant host town, then they likely do not have any trusted connection to the nuclear industry. Therefore, they receive information that they do not know how to process from sources that they do not know if they should trust regarding a risk to their quality of life. An emotional reaction to such a situation is understandable. One way this emotional reaction could have been mixed with technical understanding is through extensive public information sessions. If a proper siting process had been carried out, OPG would have had to hold public information sessions with all self-declared potential host communities. These communities would have received information in the conception phase of the project. If they ultimately decided to not host the DGR, they would have the information needed to make an informed decision and the opportunity to develop a relationship with the proponent. The issue of the general public not understanding the classification levels of nuclear waste would also be addressed through these sessions. The public would understand L\&ILW does not pose the same threat as HLW. The public sessions would make local and regional headlines that would provide surrounding communities with accurate technical information.

\subsubsection{Community Engagement}

One serious issue that was already touched upon is community engagement and how OPG defined the term "community". OPG states that one of the attractive features of their chosen site is that the community is supportive of their decision. This is true with respect to the town of Kincardine. Kincardine is the town most directly impacted by the presence of a DGR, therefore, OPG began discussions with this town in the early stages of the project. OPG and Kincardine 
have a property value protection plan that will compensate property owners for any drop in their land value due to radioactive contamination while the dump is operational (Nuclear Waste Management Organization, 2004). This agreement is only specific to properties in Kincardine although it is possible that property values in nearby municipalities could also be affected. The municipalities that face the greatest risk due to proximity are Saugeen Shores, Huron-Kinloss, Arran-Elderslie and Brockton. These municipalities do not have any property agreement with OPG. The monetary compensation they are receiving will be discussed further in the next section.

The agreement states that OPG will only compensate for loss of property value if the radioactive contamination occurred while the site was active. This is a long-term issue, after the DGR is abandoned the waste will continue to remain radioactive for many more centuries. If radioactive contamination occurs during abandonment, would anyone be eligible for compensation? While the current council of Kincardine has accepted this agreement, the generations to come may not be as satisfied. Protecting those generations is one of OPG's main incentives in constructing this repository. Nevertheless, they should not be forced to shoulder the weight of decisions made by the generations before them. There is no guarantee that in 300 years the site will remain impenetrable. There is also no doubt that the nuclear waste will remain sufficiently radioactive to require isolation from the biosphere for centuries.

In Ulrich Beck's work, Risk Society, he states that issues surrounding wealth-distribution and more recently, risk-distribution accompany modernization (1992). In the situation of the DGR, both issues exist; wealth is being distributed to communities who are most at risk, defined in terms of close proximity. These five communities mentioned above also happen to be posing the greatest risk to the DGR project. Should one of these communities oppose the construction of the DGR, OPG would face great difficulty moving forward. The residents of Southampton, a municipality in the Saugeen Shores, are strongly opposed to the DGR and feel that the risks have not been distributed evenly (Robertson, 2013). The residents of adjacent communities' worry that property values and the tourist industry would suffer not only in the extreme event of radioactive contamination but even if public perception on radioactive risk were to intensify. While Kincardine is evidently most at risk, since the site is within their borders, it is unfair to assume that neighbouring regions do not qualify for a property protection plan. OPG has complete confidence in the safety of the project; in this case, they should not have any objection 
to extending the property agreement to the nearby communities. This inclusion might assist in gaining wider community support.

Aside from these five municipalities, there are other communities who may be effected by the DGR, such as the indigenous community and international communities. The SON stressed that the DGR could not be constructed without their approval (Saugeen Ojibway Nation, 2013). They were granted this right; OPG has agreed to include the Saugeen Ojibway Nation in the regulatory approval process and is also working with Historic Saugeen Métis and the Métis Nation of Ontario (Nuclear Waste Management Organization, 2015). OPG has stated that even after receiving approval from the Minister of Environment, the approval of the SON will be necessary to proceed with construction of the facility (Saugeen Ojibway Nation 2015).

The Great Lakes and St. Lawrence Cities Initiative is a group of mayors in the Great Lakes Basin that are dedicated to protecting and restoring the Great Lakes and the St. Lawrence River (Great Lakes and St. Lawrence Cities Initiative 2015). The group took a stance against the DGR in 2013. They have maintained that stance, even though the group's new chairperson is the mayor of Huron-Kinloss who is undoubtedly in support of the project (Daniszewski 2015). The group consists of 119 towns and cities in Canada and the US including Chicago, Toronto and Kincardine (Great Lakes and St. Lawrence Cities Initiative 2015).

Another major concern is that the DGR site is uncomfortably close to the Canada-United States border. Many municipalities along the opposite shore of Lake Huron in the United States have expressed objections to the DGR construction, including the Oregon City Council (Bihn, 2013), the Michigan State Senator (Hopgood, 2013), the St. Clair County Water Quality Board (Hayes, 2008) and the City of Marine City (Lepley, 2008). The simplest, and probably most effective, way to deal with any transboundary issues in the Great Lakes Basin is to involve the IJC. If the issue is referred to the IJC, they will appoint a board of various experts from both countries. The board will then make a recommendation to both governments. Despite not being bound to comply with the IJC, both governments usually accept the recommendations (International Joint Commission 2017). The IJC has not been involved yet because both the Canadian and the American government must refer the case to the commission (McCarthy 2013). 


\subsubsection{Compensation}

Along with the property value agreement, OPG has also agreed to pay five municipalities a lump sum and annual payments if they support the construction and operation of the facility. The details of these payments can be seen in Figure 7. This agreement is not exclusive to Kincardine, which is to receive $\$ 22.1$ million over the life of the project, it includes the following adjacent municipalities as well: Saugeen Shores \$8.5 million, Huron Kinloss \$2.38 million, ArranElderslie \$1.36 million, Brockton \$1.36 million (Nuclear Waste Management Organization, 2004). According to the agreement, by 2015 OPG will have paid these municipalities a total of $\$ 15.75$ million. These amounts are calculated per nuclear facility; they are not based on the amount of nuclear waste that will be stored in the facility. Residential property values can be expected to drop quickly, once a proposal to construct a hazardous facility is submitted. OPGs decision to begin compensating the host and adjacent municipalities at the inception of the project is just although it can also be considered a bribe. Often when compensation is given early on, the proponent's intentions are doubted. If the municipality does not have enough information on the project, it may be unfair to have them agree to the facility before its impacts are clearly understood. Money given too early on in the siting process is often seen as dirty money especially when lives are at stake. This strategy only works if the facility already exists and the proposal is just for an expansion. In this case, a DGR facility does not exist, however an above ground storage facility does.

Compensation is an important aspect of hazardous facility siting. The purpose of compensation is to off-set any risks the host community will face. The main difference between compensation and bribery is that compensation is given openly while a bribe is given secretly. The compensation provided by OPG was given openly. The municipality of Kincardine is not ignorant when it comes to nuclear waste. Despite that, there are some conditions in this agreement that may be controversial. This agreement will become void if OPG believes that a municipality has not fulfilled its role in supporting the project construction after it has received the license to prepare site and construct (OPG 2004). This financial agreement makes it difficult for these five municipalities to provide an unbiased opinion of the project. Should one municipality fail to support the construction, they will no longer receive payments, even though the facility will exist. This condition is unjust; the presence of the facility will pose a perceived 
and objective risk to adjacent communities, those communities deserve to be compensated regardless of their involvement in the project.

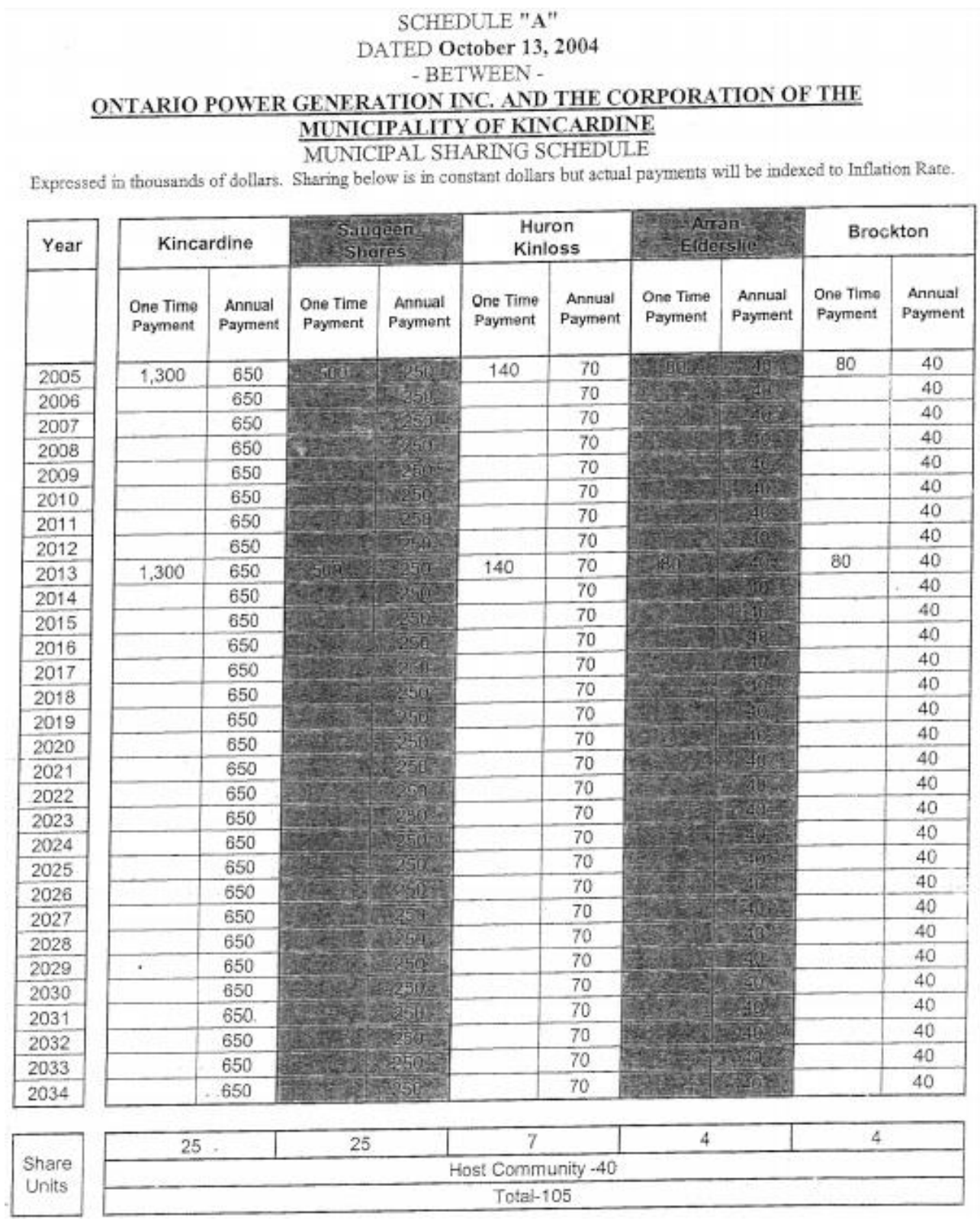

Figure 7. DGR Hosting Agreement (OPG 2004)

\section{Conclusion and Recommendations}

\subsection{Summary}

Due to the perception of high risk surrounding nuclear waste, OPG should have followed a structured siting process for the Kincardine DGR proposal. Omitting important phases of a 
cooperative siting process resulted in significant delays to the project timeline. The license to prepare site and construct should have been issued 120 days after the EA report submission. Instead, the EA was critiqued for not studying alternative sites, having insufficient mitigation plans and ignoring cumulative effects from a potential HLW DGR in the area. All of these critiques were provided by stakeholders during the public hearings. The public hearings are an opportunity for concerned citizens to voice their opinions in the hopes that their concerns will be addressed. By submitting the EA without addressing concerns raised during the public hearings, OPG devalued the communities involvement. If OPG held public hearings earlier in the siting process, the EA critiques could have been dealt with before even becoming an issue. Early public hearings would have also helped gain stakeholder trust and provided a platform for effective risk communication.

Frequent public consultation at each step of the project before finalizing a host site is the crucial phase that may have helped reduce opposition to the DGR. The HLW DGR siting process offers many opportunities for public consultation. The siting process is extensive which shows that finding the ideal site is a top priority. Perhaps it is for this reason that opposition to the HLW DGR is not as strong. Stakeholders who feel the need to oppose the HLW DGR may do so at the public meetings. The HLW DGR may face just as much, or perhaps much more, opposition as the L\&ILW DGR after finalizing a site. Although the only way to verify this is to wait until a site is finalized.

\subsection{Recommendations}

OPG still has the opportunity to mitigate the opposition. One recommendation to achieve this is to engage the community so they have a greater sense of control, even if that is as simple as providing them with transparent information on the project plan. OPG can outline a storage plan where initial waste deposits consist entirely of LLW. Once the DGR has a track record of safe performance, which can only be achieved through extensive monitoring and transparent reporting, ILW can be added as well. Residents should also have the option to be involved in monitoring contamination in the lake when the facility is operational. Stakeholders that feel they have some control over the facility are less likely to oppose it. One final recommendation is that OPG should use GIS modeling and buffer zones to study sites all across Ontario as potential host 
sites. This would show stakeholders that OPG is doing their due diligence to find an environmentally sound site.

\subsection{Contributions and Implications}

It is important to understand why there was no structured siting process and what were the implications. This understanding can help rectify this issue moving forward and prevent other proponents from side stepping a crucial process. When siting a DGR in Ontario, gaining community support is of utmost importance. This is achieved by engaging stakeholders early in the siting process, this assists with mitigating risk perception and increasing levels of trust in the proponent. This research will add a new case study to the field of hazardous facility siting and will contribute to the limited literature on siting an L\&ILW DGR.

\subsection{Limitations and Future Work}

The main limitation of this report is that the evidence gathered was only in the form of documents and archives. This research can be improved upon by gathering information from alternative sources. Two sources that may prove very useful to this research are interviews and direct observations. A researcher could interview members from the various opposition groups as well as individual stakeholders and representatives from OPG. These interviews may provide more accurate information than what is available in documented sources. A researcher could also visit the proposed site. This will result in a greater understanding of the site and the environment.

In the future, this research can also be built upon by studying the siting process of Ontario's HLW DGR and comparing the outcomes of the two processes. This is not possible at present because the HLW DGR project is far behind the L\&ILW DGR project; however, it is important to compare the outcomes of the two processes because they both are influenced by the same society, the main difference is the siting process. 


\section{References}

Adams, R. (2014). WIPP Fire - Accident Investigation Report. Retrieved from http://atomicinsights.com/wipp-fire-investigation-report/

AECL. (1994). Summary of the environmental impact statement on the concept for disposal of Canada's nuclear fuel waste. Ontario.

Aliyu, A., Ramli, A. and Saleh, M. (2015). Assessment of potential human health and environmental impacts of a nuclear power plant (NPP) based on atmospheric dispersion modeling. Atmosfera. 28(1), p. 13-26.

Beck, Ulrich. (1992). Risk Society. Sage, pp. 19-50

Bihn, S. (2013). City of Oregon, Ohio: Resolution No. 099-2013. Retrieved from http://www.ceaa.gc.ca/050/documents/p17520/93217E.pdf

Bredehoeft, J.D., England, A.W., Stewart, D.B., Trask, N.J. and Winograd, I.J. (1978). Geologic disposal of high-level radioactive wastes - earth-science perspectives. United States Geologic Survey.

Canadian Environmental Assessment Agency. (2013). Public hearing procedures: Deep geologic repository for low and intermediate level radioactive waste project. Retrieved from http://www.ceaa-acee.gc.ca/050/documents/p17520/90168E.pdf

Canadian Environmental Assessment Agency. (2014). Hearing Documents: Deep geologic repository for low and intermediate level radioactive waste. Retrieved from http://www.ceaa-acee.gc.ca/050/documents-eng.cfm?evaluation=17520\&type $=4$

Canadian Environmental Assessment Agency. (2015). Basics of Environmental Assessment. Retrieved from: https://www.ceaa-acee.gc.ca/default.asp?lang=en\&n=B053F859$\underline{1 \# \text { panel02 }}$

Canadian Environmental Assessment Agency. (2016). Considering Aboriginal traditional knowledge in environmental assessments conducted under the Canadian Environmental Assessment Act -- Interim Principles. Retrieved from https://www.ceaaacee.gc.ca/default.asp?lang=En\&n=4A795E76-1

Canadian Environmental Assessment Agency. (2016). Documents: Deep geologic repository project for low and intermediate level radioactive waste. Retrieved from http://www.ceaaacee.gc.ca/050/documents-eng.cfm? evaluation $=17520 \&$ page $=29 \&$ type $=0 \&$ sequence $=0$

Canadian Environmental Law Association. (2015). Nuclear waste watch. Retrieved from http://www.cela.ca/sites/cela.ca/files/Open-Letter-DGR-NGOs.pdf

Canadian Nuclear Safety Commission. (2015). Linear non-threshold model. Retrieved from http://nuclearsafety.gc.ca/eng/resources/health/linear-non-threshold-model/index.cfm

Canadian Nuclear Safety Commission. (2015). Ontario Power Generation deep geologic repository. Retrieved from https://cnsc-ccsn.gc.ca/eng/resources/status-of-new-nuclearprojects/deep-geologic-repository/index.cfm

Canadian Nuclear Safety Commission. (2016). High-level radioactive waste. Retrieved from http://nuclearsafety.gc.ca/eng/waste/high-level-waste/index.cfm 
Canadian Nuclear Safety Commission. (2016). Low- and intermediate-level radioactive waste. Retrieved from http://nuclearsafety.gc.ca/eng/waste/low-and-intermediatewaste/index.cfm

Canadian Nuclear Safety Commission. (2016). Public Notice Deep Geologic Repository Project - Ministerial Request for Additional Information. Retrieved from http://www.ceaaacee.gc.ca/050/document-eng.cfm?document=104963

Canadian Nuclear Safety Commission. (2016). The Commission. Retrieved from https://www.cnsc-ccsn.gc.ca/eng/the-commission/index.cfm

Chung, J., \& Kim, H. (2009). Competition, economic benefits, trust, and risk perception in siting a potentially hazardous facility. Landscape and Urban Planning, 91(1), p. 8-16. doi:10.1016/j.landurbplan.2008.11.005

Connolly, A. (2016). EKOS: Canadians trust in government at highest point in 17 years of tracking. iPolitics. Retrieved from http://ipolitics.ca/2016/04/18/ekos-canadians-trust-ingovernment-at-highest-point-in-17-years-of-tracking-ac/

Cotter, A. (2015). Spotlight on Canadians: Results from the general social survey, public confidence in Canadian institutions. Statistics Canada. Retrieved from http://www.statcan.gc.ca/pub/89-652-x/89-652-x2015007-eng.htm

Daniszewski, H. (2015). Great Lakes mayors still opposed to burying nuclear waste near Lake Huron. The London Free Press. Retrieved from http://www.Ifpress.com/2015/06/17/proposed-nuclear-waste-storage-issue-brought-up-atgreat-lakes-and-st-lawrence-cities-initiative-in-sarnia

Duinker, P. (2013). OPG case for Kincardine DGR site is "suspect" and "unreliable," expert says. Retrieved from https://www.youtube.com/watch?v=oR57KIxdEHo

Elo, S. and Kyngas, H. (2007). The qualitative content analysis process. Journal of Advanced Nursing, 62(1), p. 107-115.

Environment and Climate Change Canada. (2015). Incineration. Retrieved from https://www.ec.gc.ca/toxiques-toxics/Default.asp?lang=En\&n=0D129B0A-1

Fischer, Frank. (2009). Democracy \& Expertise. Oxford: Oxford University Press, p. 77.

Goetz, S. (2014). Ontario Power Generation ordered to resubmit DGR safety case after former OPG scientist discovered the radioactivity of materials was grossly underestimated. Kincardine News. Retrieved from http://www.kincardinenews.com/2014/03/27/ontariopower-generation-ordered-to-resubmit-dgr-safety-case-after-former-opg-scientistdiscovered-the-radioactivity-of-materials-was-grossly-underestimated

Great Lakes and St. Lawrence Cities Initiative. (2015). Member cities. Retrieved from https://glslcities.org/about-the-great-lakes-and-st-lawrence-cities-initiative/member-cities/

Guston, David. (2001). Boundary organizations in Environmental Policy and Science, Science, Technology and Human Values, 26(4), p. 399-408.

Hayes, D. (2008). St. Clair County Water Quality Board: Resolution 08-01. Retrieved from http://www.ceaa.gc.ca/050/documents/47290/47290E.pdf 
Heckman, R.A., Johnson, W.A. and T. Koldsworth. (1978). Lawrence Livermore Laboratory: Systems analysis study for waste management criteria. International Atomic Energy Agency. Retrieved from http://www.iaea.org/inis/collection/NCLCollectionStore/_Public/09/419/9419107.pdf?r= $\underline{1}$

Hinrich, R. and Kleinbach, M. (2012). Energy: Its use and the environment. Brooks Cole, $5^{\text {th }}$ Edition. Chapter 14, p. 456-463.

Hopgood, H. (2014). OPG's Deep Geological Repository (DGR) Project for Low and Intermediate Level Radioactive Waste. Retrieved from https://ceaaacee.gc.ca/050/documents/p17520/99621E.pdf

International Atomic Energy Agency. (2009). IAEA safety standards for protecting people and the environment: Classification of radioactive waste. Retrieved from http://wwwpub.iaea.org/MTCD/publications/PDF/Pub1419_web.pdf

Independent Electricity System Operator. (2016). Supply Overview. Retrieved from http://www.ieso.ca/Pages/Power-Data/Supply.aspx

International Joint Commission. (1997). Ninth Biennial Report on Great Lakes Water Quality. Retrieved from http://www.ijc.org/files/publications/C85.pdf

International Joint Commission. (2017). Role of the IJC. Retrieved from http://www.ijc.org/en_/Role_of_the_Commission

Johns, Carolyn. (2009). Water Pollution in the Great Lakes Basin: The Global-Local Dynamic. In Environmental Challenges and Opportunities. Local-Global Perspectives on Canadian Issues, Christopher Gore and Peter Stoett (eds). Toronto: Emond Montgomery.

Kuhn, R. and Ballard, K. (1998). Canadian innovations in siting hazardous waste management facilities. Environmental Management, 22(4), p. 533-545.

LaGrega, M., Buckingham, P. and Evans, J. (1994). Hazardous Waste Management. Toronto, McGraw-Hill, Ch.8, Sec. 8-4, "Site Selection", p. 426-446

Lepley, R. (2008). City of Marine City, St. Clair County, Michigan: Resolution No. 032-08. Retrieved from http://www.ceaa.gc.ca/050/documents/54654/54654E.pdf

Low-Level Radioactive Waste Management Office. (2013). Inventory summary report. Retrieved from http://www.cnl.ca/site/media/Parent/2013-CNL_LLRW-SummaryReport-Eng.pdf

Markandya, A. and Wilkinson, P. (2007). Electricity generation and health. The Lancet, 370(9591), 979-990. doi 10.1016/S0140-6736(07)61253-7

McCarthy, S. (2013). Nuclear agency aims to ease safety fears over waste site near Lake Huron. The Globe and Mail. Retrieved from http://www.theglobeandmail.com/news/national/nuclear-agency-aims-to-ease-safetyfears-over-waste-site-near-lake-huron/article15126894/

McGregor, Deborah. (2004). Coming Full Circle: Indigenous Knowledge, Environment, and Our Future. American Indian Quarterly, Summer \& Fall, 28(3 \& 4), p. 385-410. 
McTaggart-Cowen, J., A. Armour, M. McHolm, M. Chamberlain, A. Porter, G.G. Gervais, P. Rennick. (1986). Opting for co-operation. Siting Process Task Force: Low-Level Radioactive Waste Disposal.

Murugen, S. (2004). Actinides. Gale Encyclopedia of Science, p. 34-36.

Nash, K. (2005). Intent to Construct a Geologic Repository for Low and Intermediate Level Waste. Retrieved from http://www.cnsc-ccsn.gc.ca/eng/pdfs/New-Builds/1294561.pdf

National Geographic Education. (2011). Nuclear energy. Retrieved from http://education.nationalgeographic.org/encyclopedia/nuclear-energy/

Nuclear Waste Management Organization. (2004). DGR Hosting Agreement between Ontario Power Generation and Municipality of Kincardine. Retrieved from http://www.nwmo.ca/uploads_managed/MediaFiles/537_HostingAgreement.pdf

Nuclear Waste Management Organization. (2008). Views and attitudes toward nuclear waste, national survey: Final Report. Retrieved from https://www.nwmo.ca/ /media/Site/Files/PDFs/2015/11/04/17/30/188_NWMOSR-200837_IpsosReidSurvey.ashx?la=en

Nuclear Waste Management Organization. (2010). Canada's plan for the long-term management of used nuclear fuel. Retrieved from http://www.nwmo.ca/sitingprocess_feasibilitystudies

Nuclear Waste Management Organization. (2015). DGR Transition to the NWMO. Retrieved from http://www.nwmo.ca/dgrtransitiontonwmo

Nuclear Waste Management Organization. (2016). Funding Canada's plan for the safe, long-term management of used nuclear fuel. Retrieved from https://www.nwmo.ca/ /media/Site/Files/PDFs/2016/06/08/09/35/Backgrounder_Financi alSurety2016_EN_web.ashx?la=en

Ontario Power Generation. (2004). DGR hosting agreement between Ontario Power Generation and Municipality of Kincardine. Retrieved from http://www.opg.com/generatingpower/nuclear/nuclear-waste-management/Deep-GeologicRepository/Documents/HostingAgreement.pdf

Ontario Power Generation. (2013). OPG's deep geologic repository project for low and intermediate level waste. Retrieved from http://www.opg.com/generatingpower/nuclear/nuclear-wastemanagement/DGR\%20pdfs/DGR\%20Overview\%20Brochure_Updated\%20Feb\%202013 .pdf

Ontario Power Generation. (2014). Deep Geologic Repository. Retrieved from http://www.opg.com/generating-power/nuclear/nuclear-waste-management/Pages/deepgeologic-repository.aspx

Ontario Power Generation. (2014). FAQs about OPG's DGR for low and intermediate level nuclear waste. Retrieved from http://www.opg.com/generating-power/nuclear/nuclearwaste-management/DGR\%20pdfs/FAQs.pdf

Ontario Power Generation. (2016). Bruce County. Retrieved from http://www.opg.com/communities-and-partners/host-communities/Pages/brucecounty.aspx 
Ontario Power Generation. (2016). Deep geologic repository. Retrieved from http://opgdgr.com/

Ontario Power Generation. (2016). DGR public hearing. Retrieved from http://www.opg.com/generating-power/nuclear/nuclear-waste-management/DeepGeologic-Repository/Pages/Public-Hearing.aspx

Ontario Power Generation. (2016). Western waste management facility. Retrieved from http://www.opg.com/generating-power/nuclear/nuclear-wastemanagement/Documents/WWMFbrochure.pdf

Perrow, C. (1999). Normal accidents: Living with high risk technologies. Princeton N.J., Princeton University Press, $2^{\text {nd }}$ Edition. Chapter 3, p. 62-100.

Rashad, S. and Hammad, F. (2000). Nuclear power and the environment: comparative assessment of environmental and health impacts of electricity-generating systems. Applied Energy. 65(1), p. 211-229.

Robertson, K. (2013). OPG manipulated small town councils into terrible deal on DGR, says Southampton Residents Assoc. Retrieved from https://www.youtube.com/watch?v=_0ab5nmE1ZY

Saugeen Ojibway Nation. (2013). Deep Geologic Repository - Hearings. Retrieved from http://www.saugeenfirstnation.ca/downloads/DGR\%20Council\%20info.pdf

Saugeen Ojibway Nation Environment Office. (2015). SON nuclear issues factsheet \# 2. Retrieved from http://saugeenojibwaynation.ca/wpcontent/uploads/2015/09/SON_NUC_FS2.pdf

Siegrist, M and Cvetkovich, G. (2000). Perceptions of hazards: The role of social trust and knowledge. Risk Analysis. 20(5), p. 713-719.

Slovic, P. (1999). Trust, emotion, sex, politics, and science: Surveying the risk-assessment battlefield. Risk Analysis. 19(4), p. 689-701.

Stop the Great Lakes Nuclear Dump. (2016). Communities opposing OPG plan. Retrieved from http://www.stopthegreatlakesnucleardump.com/resolutions.php

Stoutenborough, J., Sturgess, S., Vedlitz, A. (2013). Knowledge, risk, and policy support: Public perceptions of nuclear power. Energy Policy. 62, p. 176-184.

Swanson, S., Archibald, J., \& Muecke, G. (2015). Deep Geologic Repository for Low and Intermediate Level Radioactive Waste Project.

United States Geological Survey. (1978). Geologic survey professional paper 1100. Retrieved from https://pubs.usgs.gov/pp/1100/report.pdf

U.S. Nuclear Regulatory Commission. (2016). Background on radioactive waste. Retrieved from http://www.nrc.gov/reading-rm/doc-collections/fact-sheets/radwaste.html

U.S. Nuclear Regulatory Commission. (2016). Becquerel (Bq). Retrieved from http://www.nrc.gov/reading-rm/basic-ref/glossary/becquerel-bq.html

U.S. Nuclear Regulatory Commission. (2016). Sievert (Sv). http://www.nrc.gov/reading$\underline{\mathrm{rm} / \mathrm{basic}-\mathrm{ref} / \mathrm{glossary} / \mathrm{sievert}-\mathrm{sv} \cdot \mathrm{html}}$ 
World Nuclear Association. (2015). International nuclear waste disposal concepts. Retrieved from http://www.world-nuclear.org/information-library/nuclear-fuel-cycle/nuclearwastes/international-nuclear-waste-disposal-concepts.aspx

World Nuclear Association. (2015). Nuclear basics. United Kingdom. Retrieved from http://www.world-nuclear.org/Nuclear-Basics/What-are-nuclear-wastes-/

World Nuclear Association. (2015). Nuclear power in Canada. Retrieved from http://www.world-nuclear.org/information-library/country-profiles/countries-a-f/canadanuclear-power.aspx

World Nuclear Association. (2016). Radioactive waste management. Retrieved from: http://world-nuclear.org/information-library/nuclear-fuel-cycle/nuclearwastes/radioactive-waste-management.aspx

Yin, R.K. (1984). Case study research: design and methods (Vol. 5, Applied Social Research Methods Series). Sage Publications.

Ziqiang, P., Zhuzhou, C., Zhiming, Z., Binglin, X., Zhonghai, M.,Jianzhong, H. and Huimin, H. (1999). Preliminary research of health and environmental impacts and greenhouse gas emission from coal-fired power and nuclear power chains in China. International Journal of Global Energy Issues. 12(1-6), p. 257-270. 